\title{
ÜNIVERSITEDE HEDIYE VERME KÜLTÜRÜ VE KURUMSAL DEĞERLERE UYGUN HEDIYELIK EŞYA TASARIMI
}

\author{
Dr. Öğr. Üyesi Nazlı Gürgan* \\ Dr. Öğr. Üyesi Mine Ovacık**
}

\section{ÖZET}

Kurum kültür nesnesi, kurumlarm kültürel özelliklerini barındiran, hediye vermek üzere tasarlanmış eşyadır. Bir üniversitenin hediyeleri, bünyesinde bulunan sanat, tasarım ve teknoloji birikimi aracıllğıyla yaratılmış ve üretilmiş kültür nesneleri olabilirken, bu üretim, o üniversitenin kendini ve değerlerini yansıtacak önemli bir araçtır. Bu fikirden yola çıkılarak uygulama temelli araştırma yöntemiyle bir tasarım projesi gerçekleştirmiştir.

Bu makalede, projenin araştırma ve tasarım uygulama süreci ve sonuçları paylaşılırken, aynı zamanda şu konular sorgulanmaktadır: Hediye verme eyleminde nesnenin rolü nedir? Gündelik yaşamda, özel hayatımızda hediye vermek kişisel bir eylemken, kurumlarda verilen hediyeler, kurumsal değerleri nasıl yansitabilir? Bir üniversitenin kurumsal değerlerini ve kültürünü yansitan nesneler nasıl tasarlanabilir? Tasarlanan bu ürünlerin görünürlüğü nasıl sağlanabilir? Tasarım değeri yüksek ürünlerin kurumsal aidiyet duygusunu pekiştirdiği bilgisiyle yola çıkılan bu projede, üniversitenin öğrenci ve öğretim elemanı çalışmalarını dönüştürerek, yerel üretim yöntemlerinin çağdaş tasarım iş birliği ile sürdürülmesine katkıda bulunarak, üniversitenin hediyelik eşya üretiminde örnek bir model oluşturma amacına ulaşılmıştır.

Anahtar Kelimeler: Hediye, Kurumsal Hediye, Hediyelik Eşya Tasarımı, Marka, Zanaat ve Tasarim.

\footnotetext{
* Yaşar Üniversitesi, Sanat ve Tasarım Fakültesi, Grafik Tasarımı Bölümü,

Üniversite Cad. No:37-39 Bornova İzmir Telefon: 02325708737

** Yaşar Üniversitesi, Sanat ve Tasarım Fakültesi, Endüstriyel Tasarım Bölümü, İzmir / TÜRKIYYE

E-posta:mine.ovacik@yasar.edu.tr
} 


\title{
GIFT GIVING CULTURE IN UNIVERSITY AND DESIGNING GIFT OBJECTS THROUGH CORPORATE VALUES
}

\author{
Assist. Prof. Nazlı Gürgan* \\ Assist. Prof. Mine Ovaclk**
}

\begin{abstract}
Corporate cultural objects are designed to be given as gifts, which represent the cultural characteristifs of that particular corporation. While gifts of a university are possibly designed and produced through its collective knowledge of art, design and technology, this production is a remarkable tool projecting values of the university. In this respect, this research is conducted as a design project with the method of practice-based research.

In this article, not only the process and outcomes of the project is shared but also, the following issues are questioned: What is the role of the object in gift giving? If gift giving in our daily life is personal, how can corporate gifts reflect its corporational values? How could cultural objects of a university that reflect its institutional culture and values be designed? How could these designed objects become visible? This research is based on the idead that products' design value reinforces corporate belonging, and aims to create an exemplary model for the production of university gift objects by turning academic studio works into products, contributing to sustainable local production methods through collaboration with contemporary design.
\end{abstract}

Key Words: Gift, Corporate Gift, Gift Design, Brand, Craft and Design.

* Yaşar University, Faculty of Art and Design, Graphic Design Department, İzmir / TURKEY

E-mail:nazli.gurgan@yasar.edu.tr

** Yaşar University, Faculty of Art and Design, Industrial Design Department, İzmir / TURKEY

E-mail:mine.ovacik@yasar.edu.tr 


\section{GİRIŞ}

Kültür nesneleri, yaygın tanımıyla hediyelik eşyalar, geleneksel olarak turistik aktivelerin başında yer almıştır. Hediye verme her kültürün ritüelleri arasında olmakla birlikte, araştırmaların çoğu turizm alanında hediyelik eşya üretimi ve satışı üzerine gerçekleştirilmiştir, çünkü günümüzde dünya çapında bölge ekonomileri açısından önemli bir katkıya sahiptir (Cohen, 2001; Evans, 2000; Morbello, 1996; Timothy, 2005). Turizm alanındaki çalışmaların ilk örnekleri, el yapımı ürünler, etnik sanatın tüketim ürünü haline gelmesi ve bu şekilde dönüşen yerel zanaatler olmuştur (Bolabola, 1980; Gormsen, 1981; Graburn, 1976; de Kadt, 1981; Schädler, 1979). Akademik düzeyde ilk kapsamlı araştırmanın 1986 yılında Beverly Gordon tarafından gerçekleştirilmesi sonrasında; tüketicisi üzerine (Anderson\&Littrell, 1995; Combrink\&Swanson 2000; Littrell vd, 1994), özgünlügü üzerine (Blundell, 1993; Littrell vd, 1993; Asplet, 2000), turist ve mağaza algıları üzerine (Swanson \& Horridge 2002; 2004; 2006), satın alma eğilimleri üzerine (Kim \&Littrell, 1999, 2001; Yu\&Littrell, 2003) araştırmalar yapılmıştır (Swanson K. K., 2006). Konu estetik, ekonomik, işlevsel ve felsefi açılardan, alışveriş, el sanatları, hediye-alma verme kültürü, tüketim, materyal kültür ile birlikte incelenmiştir (Swanson\&Timothy, 2012). Bu araştırmaların çok çeşitli disiplinlere yayıldığ ancak tasarım alanında henüz konuyla ilgili akademik bir çalışma yapılmadığı gözlemlenmiştir. Bu sebeple, kentin bir parçası olan üniversitenin kurum kültürü içerisinde hediyelik eşya tasarımı üzerine, uygulama temelli araştırma yöntemiyle bu çalışma gerçekleştirilmiştir.

Uygulama temelli araştırma; uygulama ve bu uygulamanın çıktıları hakkında özgün yeni bilgi edinmek üzere gerçekleştirilen araştırma yöntemidir. Özgünlük ve katkı, ortaya çıkarılan eser üzerinden tanımlanmaktadır. Araştırma, bir metnin kapsamında sunulmakla birlikte, uygulama çalışması görlmeden konuyu anlamak mümkün olmamaktadır (Candy, 2006).

Üniversitede verilen bir hediye neyi yansıtır? Hediye verme eyleminde nesnenin rolü nedir? Gündelik yaşamda, özel hayatımızda hediye vermek kişisel bir eylem olup hediye vereni yansıtırken, üniversitede verilen hediyeler, kurumsal değerleri nasıl yansıtabilir? Üniversitenin kurumsal değerlerini ve kültürünü yansitan hangi nesneler nasıl tasarlanabilir? Tasarlanan bu ürünlerin görünürlüğü nasıl sağlanabilir? Üniversitenin değerlerini; öğrencileri, öğretim elemanları, idari personeli, yöneticileri yaratıyorsa, kurumsal hediyeler ne kadar kişisel veya ne kadar kurumsaldır? Bu kişisellikle kurumsallık arasındaki denge tasarım değeri ile sağlanabilir mi?

$\mathrm{Bu}$ sorgulamayla üniversitenin kültürünü paylaşırken yaşatmak, sürdürmek, geliştirmek, özgünlüğünü görünür kılma sürecine tasarım ile katkı sağlamak amacıyla "Yaşar Üniversitesi Kültür Nesneleri Tasarım Stratejisi ve Bir Uygulama” başlıklı Bilimsel Araştırma Projesi (BAP) gerçekleştirilmiştir. Projede tasarlanan nesneler ile proje kapsamında; hediye verme teorisi, kurumsal kültür, kültür nesneleri-hediyelik eşya tasarımı, üretimi ve yeni tasarım-zanaat kavramları üzerine yapılan literatür araştırmasının bulguları paylaşılacaktır. Ardından, yapılan tasarım uygulaması sonuçları ve tasarımların odak grup çalışmasıyla test edilmesi ve analizi, sonuçta "tasarıma dayalı bir iş modeli" önerisi sunulacaktır. 


\section{HEDİYE VERME KÜLTÜRÜ}

Hediye, popüler kültürün bir ürünü olarak görülse de temeli arkaik toplumlara dayanmaktadır. Antropologlara göre hediye, potlaç terimiyle anlam bulur. Potlaç, kendini mahrum etme olarak tanımlanabilen, klan şefinin yiyecek ve diğer ürünlerle herkesten daha fazla vererek cömertlik gösterdiği saygınlık kazanılan bir etkinliktir (Mauss, 1966). Antik dönem Roma ve diğer medeniyetlerde benzer şekilde sürdügü gibi topluluklar arası da kullanılmıştır. Ayrıca gezi veya keşif için farklı bir coğrafyaya giden kişilerin anı nesnesi olarak getirdiği ürünler de eklenmiştir.

Hediye alma-verme kültürü teorisinin temeli, Marcel Mauss'un "An Essay on the Gift: the Form and Reason of Exchange in Archaic Societies"(1925/1954) eserine dayanmaktadır. Arkaik toplumlardaki değiş-tokuş kültürünün biçimini ve işlevini araştıran bu eser, hediye alma-verme kültürünün günümüz politik, ekonomik, sosyal ve etik kapsamda temellerini oluşturduğunun altını çizmektedir. Mauss ile başlayarak Derrida ve Bourdieu ${ }^{1}$ ile devam eden felsefi temelde, tarihsel olarak hediye verme sürecinin farklı coğrafyalarda şekillenme biçimi incelenmektedir. 19. yüzyılda 'Modern' toplumlarda Sanayi Devrimi sonrası özel günlerin artışı, hediye verme alışkanlıklarını güncel konumuna ulaştırmıştır. Özel günlerin yanı sıra, hediyelik eşyalar, ticari olarak üretilen ve satılan, satın alan kişiye deneyimini hatırlatmak üzere evrensel olarak turizmle ilişkili ürünlerdir.

\section{KÜLTÜR VE KURUM KÜLTÜRÜ}

İnsan kültürel bir varlıktır. Yaşam deneyimlerini gelecek nesillere aktarım ve iletişim becerisiyle varlığını sürdürmüştür. "Bilimsel anlamda kültür, toplumun üyesi olarak insanın, yaşayarak, yaparak öğrendiği ve aktarıp öğrettiği maddi ve manevi her şeyden oluşan karmaşık bütündür". Bütünün temeli toplum olarak kabul edilirken, kültür; kişileri birbirine bağlayıcı bir eleman olarak dil, haberleşme biçimi, sanat, inanç, töre, hukuk ve yönetim kurumlarını, üretim ve tüketim biçimini içermektedir (Güvenç, 2007, 10,14).

Bir kurumu, toplum olarak ele alırsak, kurumun kültürü, o kurumu bir arada tutan beklenti, deneyim, felsefe ve değerlerini içermektedir. Kurumun tüm birikimi, kurum içi iş akışı ve kurum dışı iletişimine yansımaktadır. Söz konusu kültürün temel bileşeni, kurumun değerleri olarak tanımlanmaktadır. Bu değerlerin paylaşımıyla, kurumun kültürü sürdürülebilecektir ki değerlerin anlaşılması önemli bir faktördür. Bu noktada, fark edilir olmak isteyen kurumun, tercih edilebilir olmak için kültür bağlamında farkındalık geliştirmesi önemlidir. Sahip olunan kültürü, iletişime dönüştürmek için, görsel iletişim ve tasarım kurum kültüründe vazgeçilmez olmaktadır.

Kurumun kültürüyle ilgili paylaşımların yarattığı algının, görsel ve tasarım çalışmalarıyla oluşturarak desteklemesi etkili bir yoldur. Bu bağlamda, kültür nesneleri ya da ürünleri bir toplum olarak kurumun kültür ürünleri, kendisini yaşatması ve sürdürmesi için destekleyici ve etkili bir unsurdur.

${ }^{1}$ Ungureanu, Camil. Bourdieu and Derrida on Gift: Beyond “Double Truth” and Paradox. Springer ScienceぬBusiness Media, 2013. 


\section{KÜLTÜR NESNESİ (HEDIYE)}

Kültür nesnesi, kentin, müzenin, üniversite gibi kurumların, tanıtımı amacıyla, kültürel özelliklerini barındıran, hediye edilmek üzere tasarlanmış, taşınabilir ürünleridir. Belirli dönemlerde kurumsal düzeyde verilen hediyeler marka ve kültürün yapılanmasını destekledikleri için kurumsal hediyenin, o kurumun kültürünü yansitan kültür nesneleri olabileceği söylenebilir. Turistik bölgelerde, anı nesnesi veya hediyelik eşyalar, kültür nesneleri olarak en bilinen örneklerdir. $\mathrm{Bu}$ ürünler, görsel değeri yüksek tasarım ürünleri olduğunda, yansıttığı kültürün markalaşması ve kullanıcısında aidiyet duygusu yaratmasına katkı sağlamaktadır. Bu nesneler, yerel yöntemlerle üretildiğinde, o yere veya kültüre ait değerleri taşımakta ve yansıtmaktadır.

İngilizce ve Fransızca'da kullanılan souvenir kelimesinin kökeni, Fransızca olup, fiil olarak hatırlama eylemini tanımlamaktadır. İngilizce’de ise bir şeyin hatırlandığı nesneye verilen isimdir. Türkçe’de kelimenin doğrudan çevirisi anı nesnesi olup, hediyelik eşya terimi yaygın olarak kullanılmaktadır. Hediye kelimesiyle çağrışımlar da bu yönde olmaktadır. "Hediye”, Arapça’da yol göstermek, doğru yola itmek anlamını taşıyan hidayet kelimesinden türemiş, sevgi ve saygı ifadesi olarak karşıllksız verilen şey, armağan olarak yerleşmiştir. Kelimenin Türkçe tanımı ise: birini sevindirmek, mutlu etmek için verilen şey, ödül, bağış, ihsandır (Coşar, 2008, 33-48). Türkçe'de anı nesnesi ile turistik hediyelik eşya aynı anlamda kullanılarak ister kendine ister hediye olarak verilebilecek şekilde satın alınmaktadır.

Kültür ürünlerinin alıcısı, o kültürü ve kendi beğenilerini paylaşmak, ait hissetmek, bulunduğu yerle ilgili o yerin dilini aktarabilmek için satın almaktadır. Tam da bu noktada, paylaşmanın bir ifadesi olarak hediye kavramı ortaya çıkmaktadır. Kültür, toplum üyelerinin paylaşımı ve aktarımı olarak değerlendirildiğinde, hediye verme ile bir kültür paylaşımı, bütünlük, sahip çıkmaktan söz edilebilmektedir. Kültürlere göre değişen hediyenin anlamı ve türleri, bireyin kurduğu duygusal bağ ile bütünleşen ve düşüncesini tam olarak aktarabileceği ürünleri seçme isteği, kategori çeşitliliği yaratmaktadır. Bireyin özgünlüğünü karşı tarafa aktarma isteği, güncel tasarım akımlarından etkilenerek oluşmaktadır.

\section{KÜLTÜR NESNESİ (HEDIYYE) TASARIM, ÜRETIMM VE SATIŞI}

Hediyelik eşyalar, üretilen, satılan ve tüketilen fiziksel ürünlerdir. Bu ürünler, yerel zanaattan, atölye ya da fabrikasyon üretime kadar az sayıda ya da seri üretim ile çeşitlenmektedir. Satın alınan hediyelik eşyalar arasında, yerel zanaatlarla üretilmiş olanlara ilgi, özgün ürün arayışında önemli bir yere sahiptir.

Hediyelik eşyanın zihinlerde canlanan anlamı, kalitesiz seri üretim ya da kaliteli ama pahalı ürünler haline gelmiştir. Benzer algının tasarımcılarda da olması sebebiyle yakın zamana kadar tasarımcıların çalışma alanı olarak dikkatini çekmemiştir. Proje kapsamında yapılan pazar ve alan araştırmasıyla elde edilen bulgular; son dönem eğilimlerle değişmekte olan bu durum sonucu tasarımcıların yeniden alana dahil olarak heyecan verici örnekler ortaya çıarttığını göstermektedir. 
Projenin pazar araştırmasında, hediyelik eşyaların temsiliyet kategorilerine göre;

1. Üniversite, 2. Kent, 3. Müze için olmak üzere, yurt içi ve yurt dışı örnekleri analiz edilmiştir. Ürünler, 1. Ürün, grafik ve ambalaj tasarımı, 2. Nesnelerin malzeme ve üretim biçimleri, 3. Ürün kategorileri açısından incelenmiştir. Bu araştırma, tasarım stratejisi için; ürün kategorileri, üretim biçimi ve malzeme kullanımı, aidiyet hissi yaratan görsel, ürün tasarımı yöntemi ve hediyelik eşya mağazası iş modeli oluşturma aşamalarında sentezlenmiştir. Örnekler çeşitli olmakla birlikte, yurt içi ve yurt dışında birkaç üniversite satış ya da üretim biçimi açısından öncü olmaktadır. İşletme biçimi olarak öne çıkan Harvard Üniversitesi mağazası, 1957 yılında bir grup öğrenci tarafından "öğrenciler için, öğrenciler tarafından” fikriyle kurulmuştur. Sonrasında, Harvard Öğrenci Ajansı olarak dünyanın en geniş kapsamlı öğrenci şirketi haline gelmiştir. Ürünler, Harvard geleneği göz önünde bulundurularak seçilmekte ve elde edilen kazanç öğrencilere burs vb. yollarla geri dönmektedir (The Harvard Shop, 2017).
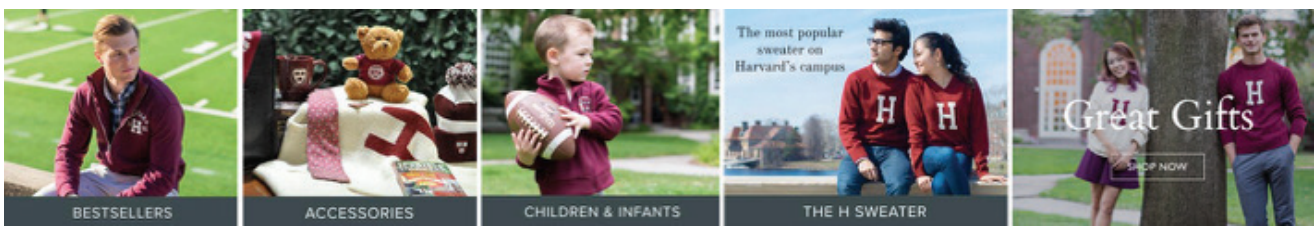

Görsel 1. "The Harvard Shop" ürün örnek kategorileri

Yerel zanaat ürünü, yerel tasarımcı iş birliği ile bünyesindeki müze/sanat galerisi hediyelik eşya kategorileriyle öne çıkan örnek ise, Glasgow Üniversitesi olmaktadır. (University of Glasgow Shops, 2017).
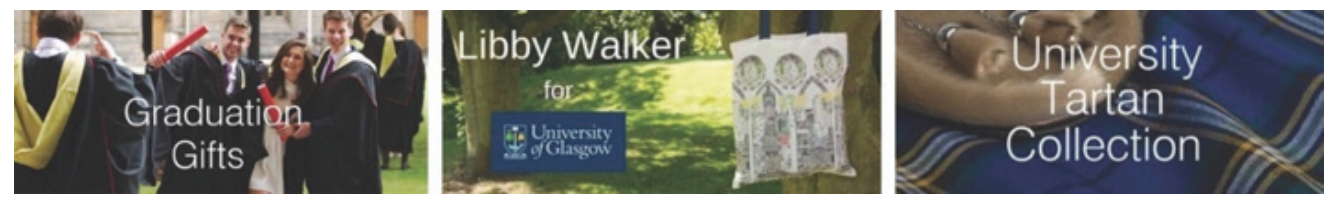

Görsel 2. Glasgow Üniversitesi hediyelik eşya mağazası ürün örnek kategorileri

Türkiye'de kent hediyelik eşyalarında en kapsamlı ve çeşitli örnekler İstanbul'da bulunmaktadır. Üniversiteler açısından ise yine İstanbul'da iki örneğin öne çıtığı gözlemlenmiştir. Bunlardan ilki, Kadir Has Üniversitesi markalı ürünleri ve sanatsal tasarımlarının satışa sunulduğu 34-14 Khas isimli üniversite mağazası, üniversitenin sahip olduğu tarihi, kişilerin üretim ve entelektüel beceri ve bilgi birikimiyle yaratılan ürünleri satışa sunmaktadır. Mağazanın tasarımı üniversitenin akademisyenleri tarafından yapılmış, ürünler yine akademisyen ve öğrencilerin üretimlerini barındırmaktadır. Aynı zamanda tasarımlar, üniversitenin tarihi çevre ve mimarisinden beslenerek üretilmekte, bulunduğu çevrede yapılan sosyal sorumluluk projelerinden üretilen işleri de kapsamaktadır. Bu mağazanın bir diğer özelliğiyse hem bir tasarım hem de bir müze mağazası olmasıdır (34-14 KHAS, 2013). 

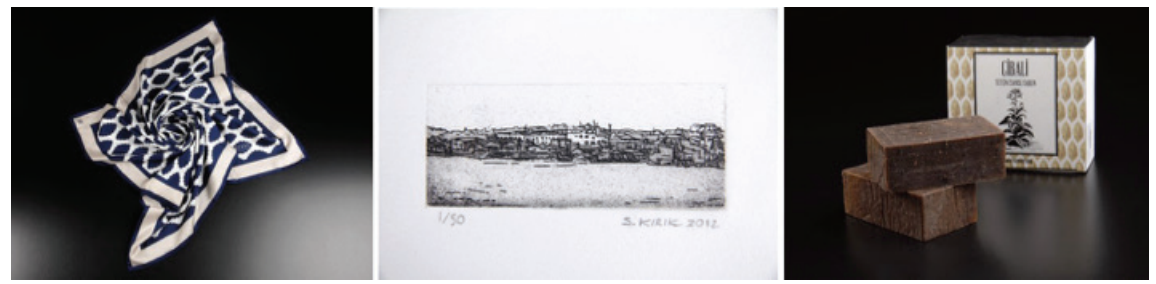

Görsel 3. Eşarp, M02 Gravür, Cibali tütün esanslı sabun

İşletme modeli ve ürün çeşitliliği açısından bir diğer önemli örnek, İstanbul Teknik Üniversitesi hediyelik eşya mağazasıdır. Konsept geliştirme ve ürün tasarımı Rektörlük Kurumsal Kimlik ve Logolu Ürün Komisyonu tarafından yapılmakta olup, gelirleri öğrencilere burs olarak dönmektedir. Ürünler; tekstil, çanta, hediyelik, kırtasiye, kitap, müzik cd olmak üzere 6 ana 34 alt kategoriden oluşmaktadır (İTÜ, 2017).

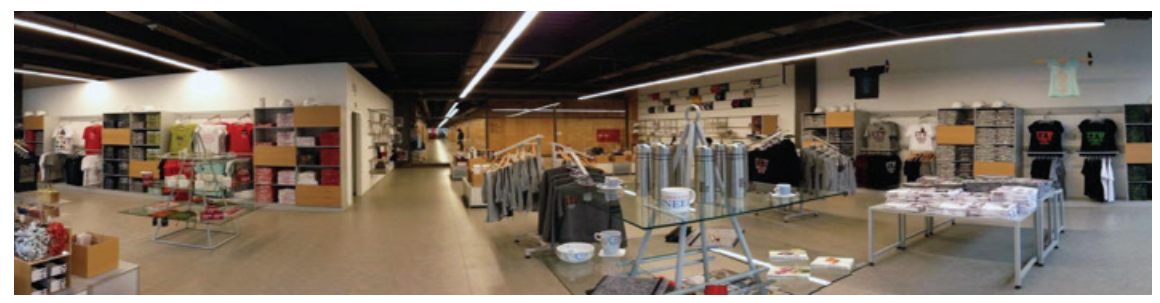

Görsel 4. İTÜ 1173 mă̆aza ve koleksiyonu

Proje alan araştırmalarında temel olarak; hediyelik eşya kategorisindeki ürünlerin tasarım uygulama modelleri; üniversite, kent, müze hediyelik eşya örnekleri yeni sezon ürün akımları ve markalaşma üzerinden incelenmiştir. Endüstrileşmiş ülkelerde söz konusu sektörün üniversite geleneğiyle bir arada olması uzun zaman önce başlamış olup, birçok farklı modelde üretim ve satış sürdürüldüğü gözlemlenmiştir. Türkiyede öne çıkan iki örnekte değerlerin üniversitenin kendi tasarım ve bilgi üretimiyle yansıtıldığı, artan üniversite sayısı ve bu üniversitelerde aidiyet duygusu oluşturma isteği ile gelişmeye yatkın bir konu olduğu görülmektedir.

Yurt dışı alan araştırmasında, hediyelik eşya veya anı nesnesi kategorisindeki ürünlerin tasarım uygulama modelleri; kent, müze hediyelik eşya örnekleri markalaşma üzerinden incelenmiştir. Londra Top Drawer ve Packaging Innovations fuarları ile Londra Tasarım Festivali kapsamında birçok etkinlik içerisinde çağdaş tasarım örnekleri incelenerek, ucuz seri üretim aksine kişisel, el yapımı, marka hikayesi ile öne çıkan ürünlere olan talep gözlemlenmiştir. Yine, özellikle turistik kentlerin başında yer almasıyla, kent hediyelik eşyalarının geleneksel olarak yerel üretimle bir arada ilerlediği ve çok çeşitli örneklerin bulunabildiği Paris’te, her yıl düzenlenmekte olan Maison\&Objet fuarı ziyaret edilmiştir. Barındırdığı çeşitlilik küresel pazarın talebine yönelik olarak oldukça kapsamlı olup, her yıl pazara ulaşmamış yeni tasarımların yanı sıra "Observatoire de la Maison" bölümünde özel olarak yenilikçi fikirler sergilenmektedir. Ayrıca 2017 yılında, "Ateliers d’Art de France” bölümünde Fransa'daki çağdaş zanaat örnekleri tanıtılmıştır. Yükselen değer olarak, geleneksel yerel üretim, zanaatin çağdaş tasarım uygulamaları ile bir araya gelmesi tüm pazar/alan araştırmaları sonucunun ortak noktası olmuştur. 


\section{HEDIYY, TASARIM VE ZANAAT}

20. yüzyılın ilk yarısında materyal kültürün üretim biçimi zanaatken, Modernizm ile yerini seri üretime bırakmıştır. Tasarımdaki tek tipleşme sorunu, sosyal, ekonomik, toplumsal diğer birçok sorunla birleşince "insani” olan yaklaşımı yeniden gündeme getirmiştir. Tarihin ironisi olarak zanaat, 21. yüzyılda tüketim kültürüne karşı, yeni bir yaklaşım olarak tasarım-zanaat iş birliğiyle yeniden ürünleriyle pazara girmiştir (Alfody, 2007). 20. yüzyılın üretim yöntemlerindeki değişimler, sanat-zanaat-tasarım ilişkileri ve tanımlarında zanaatı romantikleştirerek, geçmişin kaybolan değerleri arasına yerleştirmiştir. Son yıllarda, geleneksel üretim yöntemleriyle yeni teknolojilerin bir araya gelerek yaratıcı alanlara yeni çalışma olanakları sunması sonucu yeni nesil bağımsız tasarımcılar, günümüz zanaat öncüleri haline gelmiştir.

Designer-Maker (tasarımcı-yapıcı) olarak adlandırılan günümüzdeki tasarım hareketi, üretimin tüm süreçlerinde etkin görev alarak, tasarım ürünlerini fabrikasyon, tek tip olmaktan çıkarmaktadır. "Maker Devrimi” veya "Yeni Sanayi Devrimi” olarak adlandırabileceğimiz bu yeni eğilim, 21. yüzyıl itibarıyla tasarım üretim yöntemlerini değiştirmektedir. 19. yüzyıl sonunda William Morris ve John Ruskin'in şekillendirdiği Arts \& Crafts Akımı fikirleri, 120 yıl kadar sonra, bu sefer teknolojiden de destek alarak canlanmıştır. Geçmiş ve geleceğin teknolojilerinin buluştuğu, el yapımı ve dijital üretimi bir araya getirerek, günümüzün heyecan verici, özgün uygulamalarında yeni bir hibrid estetik ortaya çıkmıştır (Chen Design Associates, 2011, 1). Söz konusu tasarımcılar, üretimleriyle bulundukları kenti veya kurumları temsil eden hediyelik eşya olabilecek ürünleri oluşturmaları, tasarım konusu yapmaları dikkat çekicidir.

Teknolojinin demokratikleşmesi, tasarım üretimi, yapımı, ulaştırılması, satışı, öğretimi ve öğrenimi süreçlerini değiştirmektedir. İş birliği uygulamaları, tasarımcının rolünü üretim sürecinde şekillendirmektedir. Dijital fabrikasyon laboratuvarları (FabLab), tasarım ve yapım atölyeleri (maker space) artık kişisel dijital üretim sağlayıcıları olarak küresel atölye girişimleri haline gelmiştir. Bu atölyeler çoğunlukla tasarım üretiminde ortak ilgi alanlarına sahip kişiler tarafından ve onlar için yönetilmektedir. Açık ve ücretsiz bilgi paylaşımını desteklemek üzere, teknoloji ve atölye çalışmalarına erişim hakkı verilmektedir.

Yaratıcı Topluluklar (Creative Communities), Üçüncü Sanayi Devrimi’nin bir parçası olarak tanımlanmaktadır (Anderson, 2012). Söz konusu gelişmeler, ileri teknoloji ile bağlantılı olmakla birlikte, tasarımda zanaat yaklaşımını da beraberinde yükseltmektedir. The Invention of Craft ve Thinking through Craft kitaplarının yazarı Glenn Adamson’a göre zanaat; "yaratıcılığın, malzeme ve aracın birleşme noktasıdır”. Teknoloji ve malzemeler herkese açıktır ki tasarımcı kendi yerel gerçekliğinde ortaya çıkardığı ürünler ile farklılaşmaktadır. Günümüz zanaat yaklaşımı öncüleri "eski" ustalar değil, yeni nesil bağımsız tasarımcılardır. Bu bağımsızlık, "yaratıcı endüstrilerde" bir araya gelerek ülkelerin "yaratıcı ekonomilerini” oluşturmaktadır. Hali hazırda üniversite eğitimi alan tasarımcı adayları, gelecekte bu alanın parçası olacakları için eğitimlerinde bu farkındalı̆̆ı kazanmaları önem taşımaktadır.

Türkiye'de tasarım ve zanaat kültürü içerisinde geleneksel uygulamaların üzerine çağdaş yaklaşımın inşa edilmesi sıkıntılı bir süreçtir. Geleneksellik; "eski moda", "muhafazakarlık" fikri 
oluştururken, sanayileşmenin önemi ile seri üretim yüceltilmiştir. Ürün, tasarım üretim ve tüketim alışkanlıkları da bu doğrultuda gelişmiştir. Buna rağmen son yıllarda, evrensel tasarım yaklaşımlarının etkisiyle, Türkiye'de geleneksel ürün ve üretim yöntemlerinin barındırdığı potansiyel, tasarımcılar için dikkat çekici olmaktadır. Bu projede, tasarımcılar bu konulara odaklanarak üretim ve tasarım sürecine başlamıştır.

\section{7. ÜNIVERSITTE DEĞERLERINII YANSITMAK ÜZERE TASARLAMAK}

Kurum kültürünün yaratılması, tanıtımı, yaygınlaştırılması ve sürdürülmesi sürecinde hediye verme kültürüyle bağlantılı olarak, kurum kültür nesnelerinin veya hediyelik ürünlerinin oluşturulması öne çıkmaktadır. Başta öğrenciler olmak üzere tüm paydaşların ilgisini çekmek ve aidiyet hissini güçlendirmek adına kültür nesnelerinin yaratılması ve hediye edilmesi $\mathrm{ku}$ rum kültürünü oluşturma ve içselleştirme hareketinde önem taşımaktadır. Bu bağlamda kültür nesnelerinin tasarlanması ve üretilmesi konusunda, üniversitenin Sanat ve Tasarım Fakültesi, Endüstriyel Tasarım ve Grafik Tasarım Bölümlerinin iş birliğiyle örnek bir uygulama modeli ortaya koymak amacıyla yola çıkılmıştır. Bilimsel Araştırma Projesi (BAP) olarak sunulan konu kabul edilip üniversite tarafından desteklenerek gerçekleştirilmiştir. Türkiye’de kurumsal kültür ve kent kültürü nesnelerinin tasarım uygulama çalışmaları yok denecek kadar az sayıdadır. Üniversitelerin Güzel Sanatlar, Sanat ve Tasarım Fakültelerinde üretilen projelerin, tasarımların, eserlerin, ürünlere dönüşebilme potansiyeli henüz fark edilmemiş ya da fark edilip sürdürülememiştir. Bu eksikliğin varlığını bir fırsat olarak görerek, üniversitenin Sanat ve Tasarım Fakültesi akademik kadrosu ve öğrencilerinin tasarım deneyimini kurum için üreterek, kurumun öz ve özgün değerlerinin ortaya konarak kültür nesnelerini yaratmak amaçlanmıştır. Geçtiğimiz on beş yılda Yaşar Üniversitesỉnin (İzmir) akademik, fiziksel ve kültürel yapılanması dinamik bir biçimde devam ederken, üniversite kültürünün sağlamlaştırılması adına geçtiğimiz yıllarda, "Değerler Çalıştayı” gerçekleştirilmiştir. Bu çalıştay kapsamında, iç ve dış paydaşlardan oluşan çalışma grupları temel değer önerilerinde bulunmuş ve sonuç olarak: İnsan Odakllık, Toplumsal Sorumluluk, Bilimsel Yaklaşım, Yenilikçilik ve Uluslararasılık olmak üzere beş değer belirlenmiştir. Üniversitesinin Yöngörü, Temel Görev² ve beş değeri ${ }^{3}$ 1şığında, üniversite kültürünü oluşturan unsurların içselleştirilmesi adına farklı iletişim yöntemleriyle iç ve dış paydaşlar bilgilendirilmiştir.

*"BAP 019 Yaşar Üniversitesi Kültür Nesneleri Tasarım Stratejisi ve Bir uygulama" başlikl proje.

${ }^{2} Y a s ̧ a r$ Unniversitesi’ne ait; Vizyon-Yöngörü Küresel ölçekte, yenilikçi ve sürdürülebilir bir üniversite. Misyon-Temel Görev Bilim, sanat ve tasarım kültürünü benimseyen, yerel ve küresel anlamda toplumun gelişmesine katkıda bulunan eğitim, araştırma ve hizmet üretme.

${ }^{3}$ İNSAN ODAKLILIK İnsan, en önemli varlı̆̆ımızdır, onun gelişimine, mutluluğuna yönelik her türlü katklyı sağlamayı öncelikli görevimiz sayarız. İnsanın yașama, kendini geliştirme ve ifade etme hakkının en üstün hak olduğuna inanırız ve bunu güçlendirmek için çalșırız. İnsanın üreten, değiștiren ve dönüștüren gücüne inanırız ve onun bu eşsiz özelliklerini daha da geliştirmesi için çalışırız. İnsanın sorgulayan, araştıran, öğrenen, üreten, paylaşarak zenginleşen ve farkllikklarıyla biricik, saygın bir varlık olduğuna inanırız. İnsanın demokratik ilke ve kurallar çerçevesinde, en az kendi görüşü kadar bașkalarının görüşlerini de sayglyla karşılayarak, anlamaya çalş̧an, farklllıklar arasında benzerlikleri keșfederek birlikte yaşam kültürü içinde kendisini ve kurumunu geliştireceğine inanırız.

TOPLUMSAL SORUMLULUK İnsan-toplum ve çevre bağlamında daha iyi bir yaşamın sürdürülebilir kılınmasında toplumsal sorumluluğumuzun gereklerini yerine getirmek için çalıșırız. Varlğııııın ve toplumsal sorumluluğumuzun bir gereği olarak kentimizin, ülkemizin ve dünyamızın daha güzel bir hayatı yaşaması için yapılacak her türlü katklyı önemser, destekler ve bu doğrultuda çalıșırız.

BİLİMSEL YAKLAȘIM Bilginin en önemli güç olduğuna inanıriz. Evrensel bilginin birikimiyle beslenerek yeni bilgiler üretir ve insanlğ̆ı yararnna sunmak için çalışırız. Evrensel standartlara ve etik kurallara uyarak bilgiyi üretir, insanlı̆̆ın yararı için paylaşırız.

YENILIKKÇILİK Yenilikçiliğin, insanlı̆̆a yarar sağlayacak yeniliklerin teșvik edilmesiyle ilgili bir değer olduğuna inanırız. Bunun kökleșerek sürdürülebilir olmast için, özgür düşünce ve yaratıctlı̆̆ı önemine inanır ve geliştirilmesi için çalışırız. Merak eden, soru soran, araștıran, öğrenen yaratıcl, yenilikçi bireylerin yetişstirilmesi için çalışırız.

ULUSLARARASILIK Öğrencilerimizin, öğretim elemanlarımız ve tüm çalışanlarımızın uluslararası ilişkilerini gelişstirmeleri için gerekli koșulları yaratıız. Evrensel standartlarda uluslararası bilim ve eğitim ortamıı gerçekleştirmek için çalışırız. 
"Yaşar Üniversitesi Kültür Nesneleri Tasarım Stratejisi ve Bir Uygulama" adlı proje kapsamında yapılan tasarım uygulaması odaklı araştırmalar sonucunda; üniversitenin "beş değerini" benimseyen nesneler tasarlanmıştır. Nesnelerin tasarım değerleri, üniversite yaşamında çalışanlarına, öğrencilerine benimsetecek, konuklarına tanıtma amacıyla yapılandırılmıştır. Ürün ve grafik tasarımıyla, işlev, malzeme, üretim biçimi, görsel algı ve estetik gibi unsurlar amaç doğrultusunda geliştirilmiştir.

Projenin tasarım süreci ve çıktıları "Hediye Yaşar" olarak adlandırılarak bir marka önerilmiştir. Hediye Yaşar adı, çift anlamlı bir simge-söz olarak, bir yandan hediye edilecek üniversiteye ait kültür nesnelerini ifade ederken, diğer yandan hediyenin kullanıcısıyla yaşadığını, yaşattığını ve bu yaşamışlıkla bu kültürün sürekliliğine öykünmektedir. Akılda kalıcılığıyla marka olma olasılığını barındırdığı düşünülerek logo tasarlanmıştır (Görsel 5).
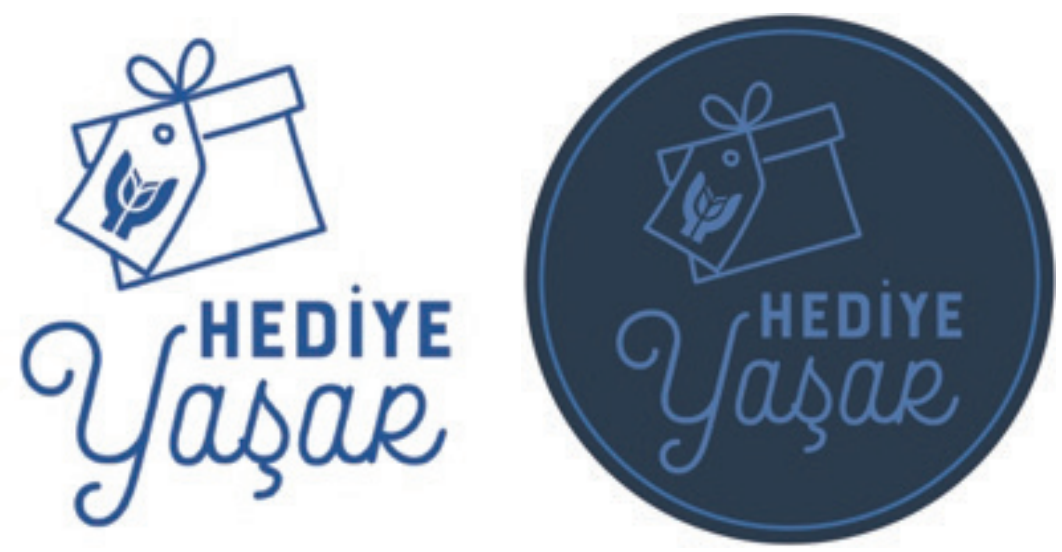

Görsel 5. Hediye Yaşar logo tasarım ve etiket uygulama.

Tasarım amacı, Yaşar Üniversitesi’nin Yöngörü, Temel Görevi ve Değerleri esas alınarak yarattığı ve yaşattığı üniversite kültürünü ve kimliğini insan odaklı bir biçimde güçlendirmek amacıyla, bünyesindeki sanat ve tasarım üretimlerinin görünürlügünü sağlayarak, kültür nesnelerini, evrensel tasarım disiplini aracıllğıyla dönüştüren ürünler yaratmaktır. Bu ürünlerin, kullanıcısınca beğenilip kullanılırken mutlulukla yaşatmasını ve böylece üniversitenin kültürünü yayması, yaşatması ve sürdürmesini hedeflenmektedir.

Tasarım tanımı, tasarım kavramlarını, hikayelerini, kullanım senaryolarını, sanat ve tasarım odaklı üniversite kültüründen edinen, üretim biçimini yerel, bölgesel ve coğrafi sosyo-kültürel değere sahip zanaat-tasarım-teknoloji ortaklığından üreten, tasarımcl-yapıcı evrensel tasarım akımının İzmirli öncüleri olarak, üniversitenin bilimsel ve teknolojik olanaklarını kullanarak, kültür nesnelerinin Hediye Yaşar adıyla tasarlanıp, üretilmesi ve kullanıcısına ulaştırılmasıdır.

Hediye Yaşar'ın hedef kitlesi; öncelikle kurum içi hediye verme gereksiniminde olan birimleri kapsamaktadır. Üniversite her yılbaşı döneminde dış paydaşları ile akademik ve idari personeline hediye vermektedir. Ayrıca her birimin yıl içerisinde hediye vermek istediği konukları olduğu gibi, ziyaret ettiği ve kendi kurumundan hediye götürmek istediği etkinlikler de mevcut- 
tur. Yurt içi ve yurt dışından öğrenci adayları, öğrenci, mezun, akademik ve idari personel konukları, üst düzey yönetici ve paydaş kurumların yöneticileri, yurt içi ve yurt dışı diğer üniversitelerin temsilcileri tasarlanan ürünlerin kullanıcısı olarak düşünülmektedir. Söz konusu hedef kitleye önemli dönemlerde hediyenin verilebilmesi, ya da hediye verilmek üzere alınabilmesi ancak kurum içinde sürdürülebilir bir üretim ile mümkün olacaktır. Bu yöntemi sağlamanın ve görünür olmanın başlıca yolu da hediyelik eşya mağazası bünyesinde barındırmaktır. Böylece kurumsal düzeyde verilen hediye aynı zamanda kurum içerisindeki kişilerin bireysel alımına da imkan verecektir.

Belirlenen Tasarım Amacı, Tanımı ve Hedef Kitle doğrultusunda ilk aşamada ürün çeşitleri üzerine yapılan beyin fırtınası sonucu ürün kategorileri: Kırtasiye ve Tekstil Ürünleri, Aksesuar, Yayın ve Dijital Medya, Sanat ve Tasarım Özel Ürünleri olarak belirlenmiștir. Üniversitenin hediye verme dönemlerinin (yılbaşı, mezuniyet, tercih ve kayıt dönemi gibi) takibi ile bu kategorilerdeki ürünlerin, sanat ve tasarım fakültesi akademisyenleri, öğrenci ve mezunları ya da yerel zanaatkar/tasarımcılar tarafından, geri dönüşüm, değer arttırımı, yeniden kullanım yöntemleri ve olabildiğince yerel, çevre dostu malzemeler ile üretimi yine mümkün olduğunca üniversite bünyesindeki grafik tasarım ve endüstriyel tasarım atölyeleri ya da yerel üretim tesislerinde yapılması planlanmıştır. Bu ölçütler ışığında, proje uygulama çalışmalarının ikinci aşamasında ürün setleri oluşturularak tasarlanacak ürünler belirlenmiştir: 1. Mezuniyet Seti (şal / kravat, anahtarlık ve bir kutu) 2. Her Gün Herkes İçin Ürünler: çeşitli tekstil ve kurtasiye ürünleri, 3. Üst Düzey Kurumsal Ürünler: deri ürün ve aksesuarlar, 4. Üst Düzey Kişisel Ürünler: kahve fincanı ve ahşap altlık, 5. Yerel Ürünler: zeytinyağı sabunu ve sabunluk, 6. Gıda: çikolata, 7. Paket malzemeleri.

Hediye Yaşar ürünlerinin tasarım ve prototip üretimi aşamasında, ilk çalışmada belirlenen ürün kategorileri ve ürün tasarımı ölçütlerine dayanarak grafik tasarım ve ürün tasarımları yapılmıştır. Strateji; tanıtım nesnesi olarak yaygınca bilinen işleve sahip ürünlerin (anahtarlık, ajanda, kupa vb.) ve bunlara ek olarak yeni işlevlere sahip, üniversitede kullanılabilecek, tasarım-zanaat-teknoloji üçlemesiyle yukarıda sıralanan ürün tiplerinin tasarlanmasıdır. Tasarımların bir kısmı dijital ortamda modellenmiş, bir kısmıysa fiziksel prototipleri üretilerek sunulmuştur.

Grafik tasarım çalışmalarında, yüzey örüntü tasarımı (surface pattern design) ağırlıklı olarak kullanılmıştır. Doğal ve yapay çevrede karşılaşılan, tekrar eden formlar yaratarak düzen oluşturma yöntemi, yüzyıllardır mimari, tekstil vb. alanlarda kullanılarak tasarımın önemli bir yöntemi haline gelmiştir. Örüntü tasarımı bir çevreyi dönüştürme, bir kültürün hikayesini anlatma, geleneği temsil etme, birlik sağlama konularında işlevseldir. Kültürel olarak ait olma hissi yaratılmasının yanı sıra, görsel algıda denge yaratarak tatmin edici bir bir etki oluşturmaktadır (Koepke, 2016, 1).

Proje uygulamaları için, üniversitenin logosu, değerler logosu ve üniversite hayatından esinlenerek oluşturulan ikonlardan, üç tipte yüzey örüntü tasarımı ürünlerin üzerine uygulanacak şekilde hazırlanmıştır. Bu görseller kendi içlerinde farkı boyut ve renklerde uygulandığı takdir- 
de, benzer görünmedikleri için farklı hedef kitlelere yönelik, her sezon yeni bir tasarım hissi yaratılmasına imkân vermektedir. Üretilen görsellerin farklı uygulamalarıyla oluşan çeşitler arasından biri seçilerek, mezuniyet ve kurumsal setler için tasarlanan ürünlere, dijital baskı ve endüstriyel tasarım bölümü atölyesinde lazer kesim yüzey işleme yöntemleriyle uygulanmıştır (Görsel 6).

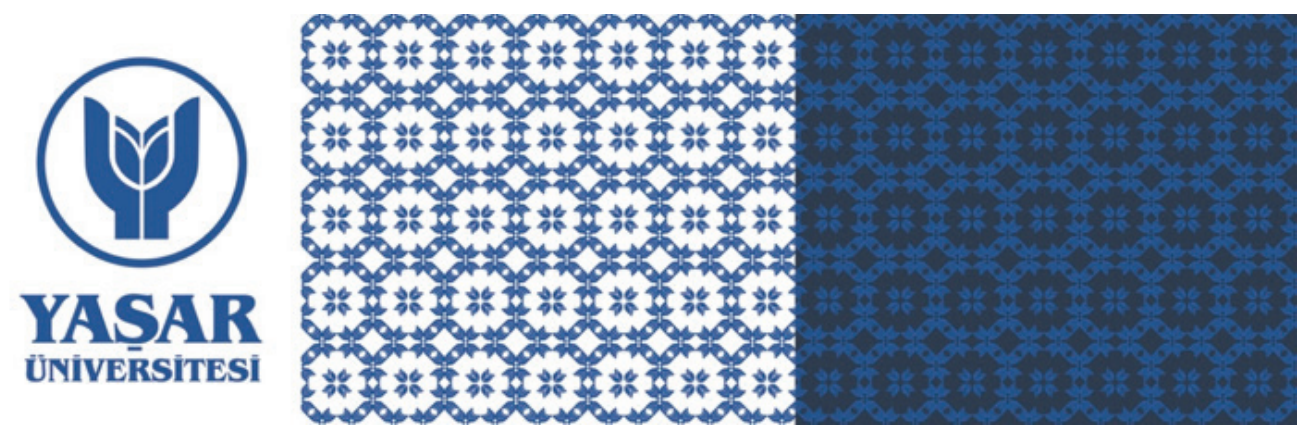

Görsel 6. Yaşar Üniversitesi logosu ve logodan üretilmiş örüntü.

Yaşar Üniversitesi değerlerini temsil eden mevcut değerler logosu, ürünlerin üzerine bir desen gibi uygulanacak biçimde yeniden düzenlenerek grafik tasarım çalışması yapılmıştır. Çalışma, deri, ahşap vb. malzeme üzerine lazer kesim yöntemiyle Her gün, Herkes İçin ürün seti ve Kurumsal Üst Düzey ürün setleri olarak uygulanmıştır (Görsel 7).
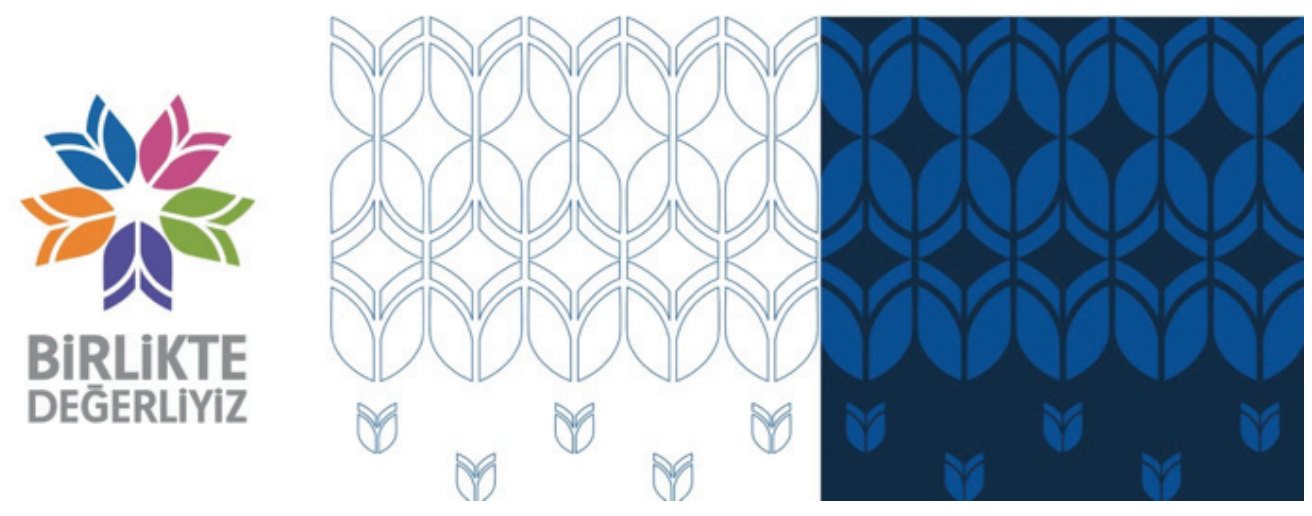

Görsel 7. Yaşar Üniversitesi değerler logosu ve logodan üretilmişörüntü.

Tercih-kayıt dönemlerinde, tanıtım fuarları ve okul gezilerinde, aday öğrenci ve üniversite öğrencilerine hediye edilebilecek ürünler için gençlerin gündelik yaşamına uygun yeni bir örüntü çalışması yapılmıştır. Bunun için öncelikle, üniversite yaşamına dair akademik, sosyal vb. alanları temsil eden 17 parçadan oluşan ikon seti tasarlanmıştır. Her ikona, yine güncel yaklaşımlar arasında olan Memphis Tasarım tarzına gönderme yapan geometrik şekiller eklenerek kendi kompozisyonları oluşturulmuştur. Bu kompozisyonlara 7 adet yardımcı geometrik şekil de eklenerek dağınık tekrar yöntemi ile tasarlanan örüntü, tüm yüzeyleri kaplayacak şekilde kullanılabildiği gibi, her bir ikon, tek ve büyük boyutta da ürün üzerinde kullanılabilmektedir. Bu ikonlar ve örüntü, proje ürünleri üzerine dijital baskı yöntemiyle uygulanmıştır (Görsel 8). 


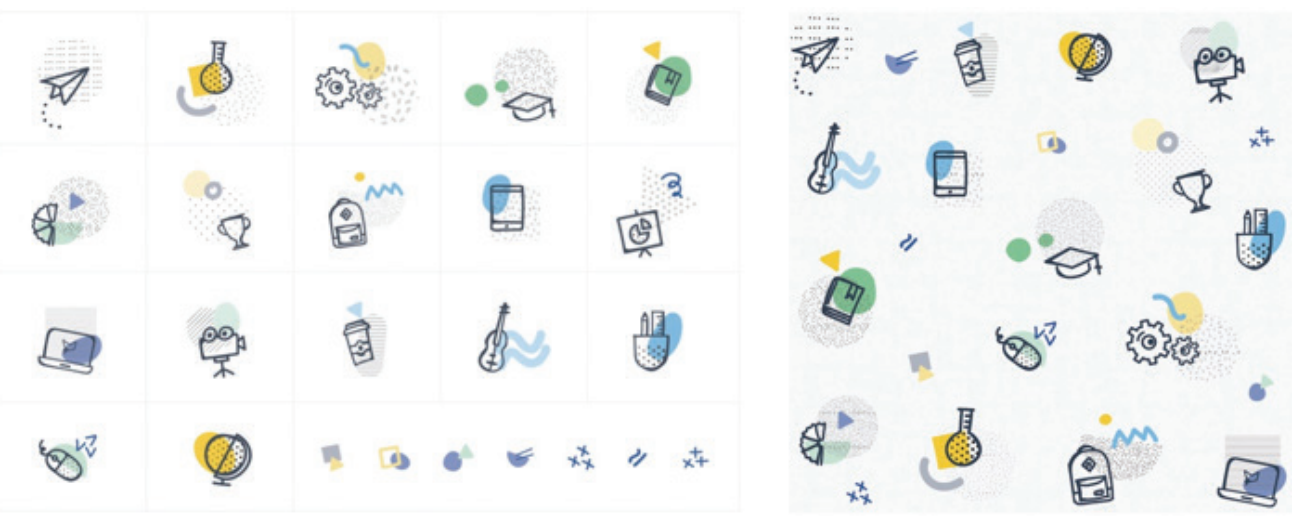

Görsel 8. Universite hayatından esinlenerek tasarlanan ikonlar ve örüntü tasarımı.

Ürün Tasarımı aşamalarında; üniversite yaşamında gerek öğrencilerin, mezunların, gerekse akademik ve idari personelin gündelik ve iş yaşantılarındaki eylemler, alışkanlık ve davranışları gözlemlenip incelenerek, ihtiyaçları göz önünde bulundurularak farklı işlevlerdeki ürün tipleri oluşturulmuştur. Tasarlanan üç boyutlu ürünlerin üzerine üniversitenin değerlerini yansıtması amacıyla, beş değerin metinlerinden esinlenilerek üretilen simge-sözler yazılarak yüzeyde uygulanmıştır.

Farklı işlevli ürün tipleri arasında; deri anahtarlık, deri el çantası, A4 ve A5 ebadında Sekreterlik olarak adlandırılan klipsli kağıt plakası, üniversite içinde dolaşım esnasında cüzdan, çanta taşımaksızın okul kimlik kartı, para konulabilecek, ince bir cüzdan gibi ya da kartvizitlik olarak da kullanılabilen Kartlık vb. ürünler farklı malzeme denemeleriyle tasarlanıp prototipleri üretilmiştir. Bu ürün tiplerinde, kullanıcıların tasarım değeri yüksek olan nesnelere karşı beğenileri gözlemlenerek ürün-nesne bağlamında bağlayıcı bir unsur olarak ürünlerin görsel kimlikleri, malzeme ve renk seçimleri yapılmıştır. Malzeme seçiminde doğal, doğa dostu ahşap, deri gibi organik malzemeler tercih edilmiştir. Bu nesneler, üniversitenin Endüstriyel Tasarım Prototip Atölyesi CAD, CAM olanakları çerçevesinde üretilebilecek biçimde tasarlanmış ve üretilmiştir. 


\section{TASARIM PROTOTİPLERİ DEĞERLENDİRME ANKETİ VE ANALIZİ}

Hediye Yaşar ürünlerinin, Yaşar Üniversitesi’nin beş değerine dayanarak tasarlanan toplamda 28 ürünün 10 adedinin prototipi üretilmiştir. Ürünler, üniversitenin tanıtım birimlerinde görevli kişilerden oluşan bir "odak grup" ile değerlendirilmiştir.4 Tasarımlar ilgili bir sunuşun ardından, tasarımların görsellerini içeren "Semantik Diferansiyel”’5 (Krippendorff, 2006, 149) (Osgood, 1957) araştırma yöntemi temel alınıp konuya uyarlanarak oluşturulan bir anketle ürünler katılımcılarca test edilip değerlendirilmiştir.

Bu çalışmada; üniversitenin tanıtımı amaçlı etkinlik, toplantı, önemli günlerde "hediye verme" işlerinde görev alan, aynı zamanda üniversitenin idari ve akademik personeli olarak "hediye alan" personelin deneyimleriyle bilgi birikimlerinin, tasarımların ürün-üniversite kültür kimliği bağlamında uygunluğunun değerlendirilerek test edilmesi amaçlanmıştır. Bu amaçla katılımcıların, tasarımları kurumsal değerlerle ilintisini ve birer kullanıcı olarak ürünleri; işlev, estetik, kullanışlılık ve verdiği aidiyet duygusu açısından değerlendirmeleri istenmiştir. Katılımcılar, ilk sunuşu izledikten ve prototipleri ellerine alarak inceledikten sonra değerlendirmeleri yapmışlardır.

Ankette 28 üründen, 14 adedi $\mathbf{M}$ ve geri kalanıysa $\mathbf{H}$ kodlarıly iki grupta sınıflandırılmıştır. Mezunlar, üniversite personeli ve üst düzey yönetici kullanıcı kitlesine yönelik ürünler; Şal, Kravat, Deri ve Ahşap ürünler, Gıda ve Yerel ürün önerileri M koduyla gruplanırken, öğrencilere yönelik giysi, kırtasiye eşyaları gibi grafik tasarımların uygulandığı ürünler $\mathbf{H}$ koduyla sınıflandırılmıştır.

Anket, üç bölümden oluşmaktadır: 1. Bölüm, katılımcıya verilen ön bilgiyi ve katılımcının göreviyle ilgili soruları içermektedir. 2. Bölüm, 28 ürünün değerlendirildiği tabloları içermektedir. Bu tabloların altında ayrılan alan, katılımcının yorum ve önerilerini de ekleyebilmesine olanak vermektedir. 3. Bölümde ise, tüm ürünlerin, katılımcının görevi gereği hediye verebilecekleri ve kişisel olarak üniversitede açılabilecek hediyelik eşya mağazasından satın alıp hediye edebilecekleri tercihlerini yaparak değerlendirmeleri istenmiştir.

Kullanıcının, anketteki tablolarda belirtilen ürünleri üniversitenin 5 değeri ile karşılaştırarak, çok-orta-az olarak sözel ve 5 ile 1 arası sayısal ölçütlerle değerlendirmeleri istenmiştir. Her bir değerlendirilecek ürün, ilgili tabloda ürünün adı ve koduyla ifade edilip, görseliyse hatırlatıcı unsur olarak eklenmiştir. Değerlendirme yöntemi hakkında katılımcılara rehberlik edecek örnek şu şekilde anketin başında aktarılmıştır: Tablolarda görülen tasarımlar Çok (5-4) - Orta

${ }^{4}$ BAP019 Yaşar Üniversitesi Kültür Nesneleri Tasarım Stratejisi ve Bir Uygulama adlı projenin ürün değerlendirme toplantısı 10 Mayıs 2017 Çarşamba günü saat 10:00’da YÜ Senato Odasinda; Halkla İlişkiler Tanıtım Pazarlama Müdürlüğ̈̈nden İpek Hepekiz, Neslihan Takmaz, Kariyer ve Mezunlar Merkezi Müdürlüğ̈̈’nden Dr. Senem Yılmaz ve Sema Abdurrahmanoğlu, Uluslararası İlişkiler ve Programlar Ofisinden Beti Barki ve Meriç Güzel'in katıllmıyla 10 Mayıs 2017 tarihinde gerçeklești.

${ }^{5}$ Semantik Diferansiyel Analiz Yöntemi: Ürün ve marka kimliği uyumu ilişkisini semantik olarak kullanıcının algısı çerçevesinde analiz etme yöntemidir. "Dilde, ürünler kavramsallaştırılır, inşa edilir ve iletilir, anlamları müzakere edilir ve kaderleri belirlenir" (Krippendorff, 2006: 149). Osgood, Suci ve Tannenbaum’un (1957) araştırmanın amacını maskelemek için konu dişı seçenekler eklenebileceği gibi konseptin irdeleneceği konu, seçim ölçeğini belirler. Bir başka kriter, belirli çalışmalarda konsept ve konu için "semantik kararlılık" ölçeği olarak açıklanmıştır. Buradaki Anket çalışmasında kullanılacak sıfatlar, araştırmanın konusuyla paralellik göstermek zorunda olduğu için, Yaşar markasını ifade edebilecek anahtar kelimeler seçilmiş ve marka karakterinin tasarlanan ürünlerle uyumunun analiz edilmesi amaçlanmıştır. Proje kapsamında bursiyer olarak Can Güvenir (PhD adayı ve Endüstriyel Tasarımcı), anket çalışmaları analizi ve prototip uygulamalarında görev almıştır 
(3) - Az (2-1) ifadeleri ve sayısal değerleriyle farklı derecelerde seçilebilecektir. Örnek olarak, Yenilikçilik değeri üzerinden, 5 ve 4 değerinin: “Tamamen yenilikçi” olduğunu; 3 değerinin: Nötr olduğunu; 2 değerinin "kısmen yenilikçi” olduğunu; 1 değerinin ise "hiç yenilikçi” olmadığını ifade ettiği bir örnek tablo ile açıklanmıştır.

Anket sonucu analiz raporunun birinci bölümünde, katılımcıların görevleri gereği; "kimlere hediye verdikleri” sorusuna verilen cevaplarla; üniversitenin kurumsal kültür nesnelerinin kullanıcı kitlesi dökümü, "ne zaman hediye verdikleri” sorusuna verilen cevaplarla; üniversitenin idari ve akademik takviminde kurumsal nesnelerin en yoğun kullanıldığ dönemler ve etkinlikler, "ne amaçla hediye verdikleri" sorusuna verilen cevaplarla; tanıtım, prestij, ciddiyet ve kurumun görsel olarak hatırlanması gibi öne çıkan fikirler, "ne hediye veriyorsunuz?" sorusuna cevaplarla; kurumun mevcut hediyelik eşya listesi, "nasıl bir hediye vermek isterdiniz?” sorusuna cevaplarla; mezunlara ve özel konuklara daha yaratıcı, dikkat çekici, farklı, akılda kalıcı ve hediyeyi alan kişinin keyifle kullanabileceği ürünler olması gibi sıfatlar öne çıkmaktadır.

Anket sonucu analiz raporunun ikinci bölümünde, ürünlerin 5 ile 1 arası sayısal değerlerle, yenilikçi, insan odaklı, bilimsel, toplumsal ve uluslararası odaklı ölçütleriyle katılımcıların değerlendirme sonuçlarının ortalaması alınarak tablolar oluşturulmuştur. Bu ankette katılımcıların birer kullanıcı olarak, tasarımların üniversitenin beş değeriyle ilişkisini işlev, estetik, kullanışlılık ve verdiği aidiyet duygusu açısından değerlendirmeleri-ne göre; Tamamen Yenilikçi Ürünler olarak; M03-Ahşap Sekreterlik, M05-Çikolata, M06- Sabun, M07- Kahve Seti, M08Telefon Kılıfı, M09- Anahtarlık 1, M10- Anahtarlık 2, M11- Kartlık 1, M12- Kartlık 2, M13Deri Sekreterlik, H01- Askı Anahtarlık, H02- Bez Çanta, H03- Beyaz Defter, H04- Kraft Defter, H05- Kalemlik, H06- Silgi, H07- USB, H09-H10 T-Shirt (K-E), H11- Sweatshirt, H12- Buff ve H13 Ayakkab1, H14- Şapka, Tamamen İnsan Odaklı Ürünler olarak; M01- Şal, M02 Kravat, M03-Ahşap Sekreterlik, M04- Kutu, M05-Çikolata, M06-Sabun, M07-Kahve Seti, M08-Telefon Kılıfi, M09- Anahtarlık 1, M10- Anahtarlık 2, M11- Kartlık 1, M13- Deri Sekreterlik, H01- Ask1 Anahtarlık, H02- Bez Çanta, H03- Beyaz Defter, H04- Kraft Defter, H05- Kalemlik, H06- Silgi, H07- USB, H08 Dolma Kalem, H09-H10 T-Shirt (K-E), H11- Sweatshirt, H12- Buff, H13 Ayakkab1, H14- Şapka, Tamamen Bilimsel Ürünler olarak; M06- Sabun, M07- Kahve Seti, M11Kartlık, M11- Kartlık 1, Tamamen Toplumsal Ürünler olarak; M06- Sabun, M07- Kahve Seti, H01- Askı Anahtarlık, H02- Bez Çanta, H03- Beyaz Defter, H04- Kraft Defter, H05- Kalemlik, H09-H10 T-Shirt (K-E), H11- Sweatshirt, H12- Buff ve H13 Ayakkabı, H14- Şapka, Tamamen Uluslararası Ürünler olarak; M02 Kravat, M04- Kutu, M05-Çikolata, M06-Sabun, M07-Kahve Seti, M08-Telefon Kılıfi, M09- Anahtarlık 1, M10- Anahtarlık 2, M11- Kartlık 1, M12- Kartlık 2, H01- Askı Anahtarlık, H02- Bez Çanta, H03- Beyaz Defter, H04- Kraft Defter, H05- Kalemlik, H07- USB, H09-H10 T-Shirt (K-E), H11- Sweatshirt, H12- Buff, H13 Ayakkabı, H14- Şapka seçilmiştir.

Anket sonucu analiz raporunun üçüncü bölümünde ise, katılımcıların görevleri gereği hangi ürünleri hediye etmek için tercih ettiklerini " $G$ " harfi ile işaretlemeleri istenmiştir. Aynı zamanda, "Hediye Yaşar" isimli hediyelik eşya mağazası olsa hangi ürünleri kişisel olarak satın alıp 
hediye etmek istediklerini " $K$ " harfi ile işaretlemeleri istenmiştir. Bu değerlendirme sonucunda; M kodlu ürünler arasında görev gereği en çok tercih edilen ürünler; 5 kişinin tercihiyle M11 Kartlık 1, 4 kişinin tercihiyle M03- Ahşap Sekreterlik, M09- Anahtarlık 1 ve M11- Kartlık 1 seçilmiştir. Kişisel kullanım için en çok tercih edilen ürün, 4 kişinin tercihiyle M07- Kahve Seti olmuştur. H kodlu ürünler arasında görev gereği en çok tercih edilen ürünler; 5 kişinin tercihiyle H01-Askı Anahtarlık, H06- USB, H04- Kraft Defter, H08- Dolma Kalem, 4 kişinin tercihiyle H02- Bez Çanta, H03-Beyaz Defter, H05- Kalemlik, H07-Silgi seçilmiştir. Kişisel kullanım için en çok tercih edilen ürün, 4 kişinin tercihiyle H01- Askı anahtarlık olmuştur.

Odak Grup Prototip Testi sonucunda, katılımcıların ürün değerlendirmelerine bakıldığında tüm ürünler arasında; M01 Şal, M03 Deri sekreterlik bilimsellik ve toplumsal değerleriyle ilişkisi, M09-M10 kodlu Anahtarlıklar, M12- Kartlık 2, M13- Deri Sekreterlik ve M14- Deri Çanta, sadece bilimsellik değeriyle ilişkisi, Az (2) ölçütleriyle değerlendirilerek zayıf bulunmuştur. $\mathrm{Bu}$ 7 ürün dışında diğerleri, Çok (5-4) ve Orta (3) ölçütleriyle değerlendirilmiştir. 28 ürünün beş değerle ilişkisinde alabileceği en fazla değer 25 en az değer 5 olabilecek bir aralıktadır. Bu aralık içinde, her ürünün aldığı toplam puanlarda en yüksek değeri 23 puan ile M07 Kahve Seti alırken, en düşük değer olan 14 M01-Şal ve M14-Deri Çantaya verilmiştir (Tablo 1).

Tablo 1: Ürünlerin beş değer ile ilişkisine verilen sayısal değerlerin toplam puanları.

\begin{tabular}{|l|l|}
\hline Puan & Ürün İsmi \\
\hline 23 & M07-Kahve Seti \\
\hline 22 & H01- Askı Anahtarlık, H03- Beyaz Defter, H12- Buff, H13- Ayakkab1 \\
\hline 21 & $\begin{array}{l}\text { M06- Sabun, M11 Kartlık 1, H02- Bez Çanta, H04- Kraft Defter, } \\
\text { H05-Kalemlik, H11- Sweatshirt, H14- Şapka }\end{array}$ \\
\hline 20 & H09-H10- T-Shirt (K-E) \\
\hline 18 & M05- Çikolata, M08-Telefon Kilıf, \\
\hline 17 & M02- Kravat, M09-M10 Anahtarlık 1-2, M12-Kartlık 2, H06- Silgi \\
\hline 16 & M13- Deri Sekreterlik, H08- Dolma Kalem \\
\hline 15 & M03- Ahşap Sekreterlik \\
\hline 14 & M01- Şal, M14- Deri Çanta \\
\hline
\end{tabular}

Çalışmanın sonunda ürünlerin toplam puanın en alt seviyesi 14 olup, 21 üründe çok ve orta olarak değerlendirilmiş olması, ürünlerin üniversite değerleriyle semantik ilişkisinin işlevsellik, estetik, kullanışlılık ve aidiyet duygusu vermesi bağlamında kullanıcı algısına büyük oranda hizmet ettiği, katılımcıların değerlendirmelerinde tespit edilmektedir.

Yapılan iki saatlik çalışmada altı katılımcı ürünleri değerlendirdiği anketleri teslim etmiş, alınan cevaplar ve yorumlar proje ekibi tarafindan analiz edildikten sonra, sonuca uygun olarak ürün tasarımları revize edilerek nihai prototiplerin üretimi tamamlanmıştır. Ürün grubuna bir tek yeni bir ürün olarak üniversitede akademik personele verilen "Başarı Belgesi Dosyası" eklenmiştir. Hediye verilecek duruma uygun hazırlanmış ürün grupları aşağıdaki gibidir:

1. Mezuniyet Seti: ahşap kutu içerisinde şal/kravat, kartlık ve anahtarlık içermektedir. Yüksek kalite malzeme ile üretilen ürünleri ile, mezuniyet haricinde ziyaretçilere de verilebilir. Ayrıca, 
yüzey tasarımında renk, görsel boyutu ya da kutu malzemesinde (ahşap yerine metal gibi) küçük değişiklikler ile ilerleyen yıllarda farklı bir görünüm kolaylıkla elde edilebilecektir (Görsel 9).
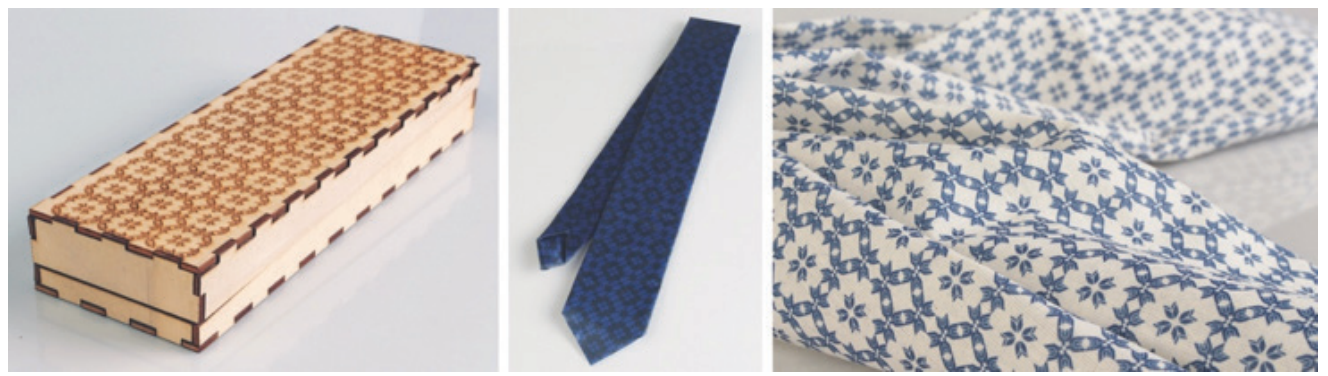

Görsel 9. Mezuniyet Seti: M04 Ahşap Kutu, M02 Kravat, M01 Şal. Logodan örüntü grafik tasarım çalışması uygulamaları.

2. Her Gün Herkes İçin Ürünler (Öğrencilere Yönelik İkon Setli Tasarımlar): Üniversitenin farklı bölümlerindeki öğrencilerin okul ve sosyal hayatından esinlenerek tasarlanan ikonların yer aldığı örüntü (yüzey) tasarımı, öğrencilere yönelik tekstil ve kırtasiye olmak üzere birçok ürüne uygulanmıştır. Değerlendirme Toplantısı sonucu olumsuz bir geribildirim alınmamış olması sebebiyle ürünlere müdahale edilmemiştir. İkonların tek ya da örüntü olarak kullanımına, ürünlerin çeşitlendirilmesi olasıdır (Görsel 10).

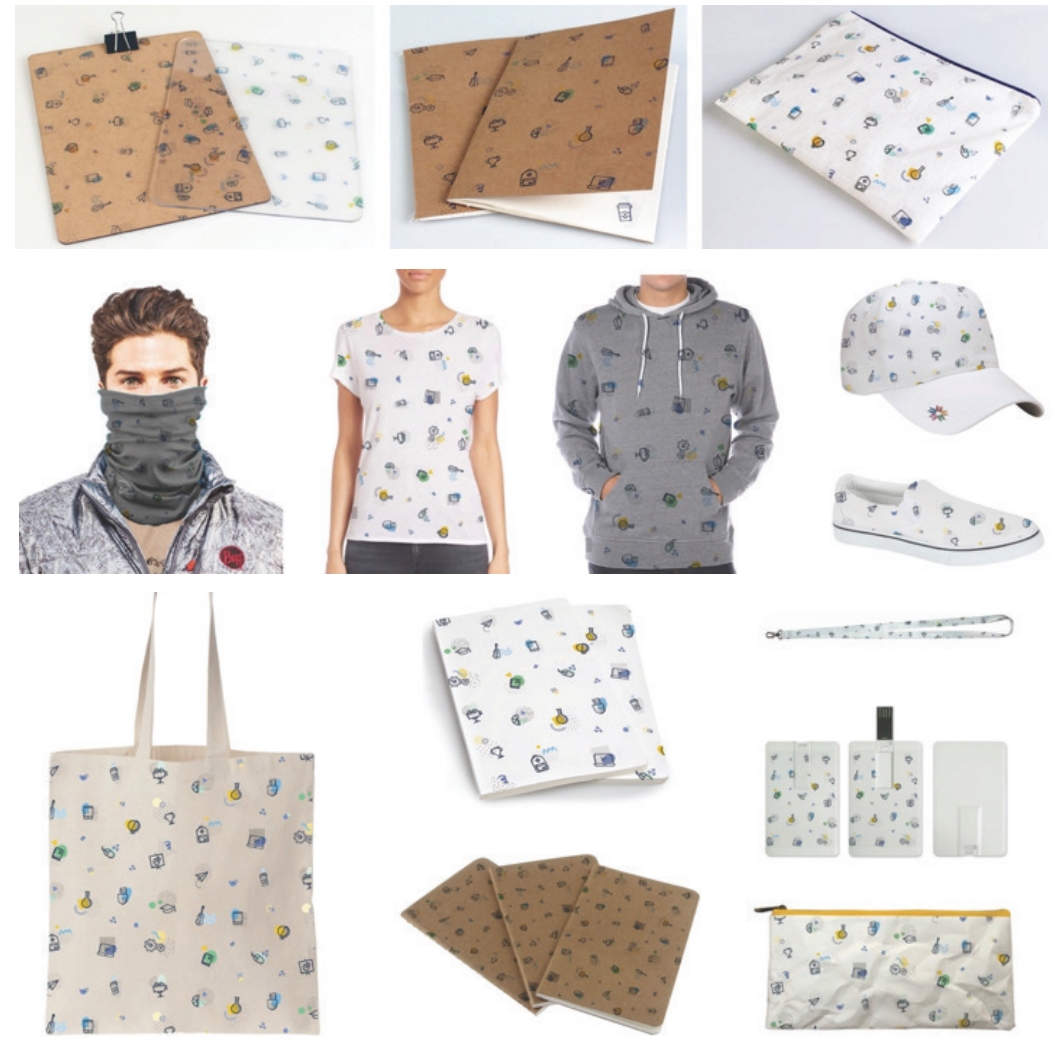

Görsel 10. H grubu ürünler: Öğrencilere yönelik, ikon örüntü tasarımlı tekstil ve kırtasiye ürün uygulamaları. 
3. Başarı Belgesi Dosyası ve Sekreterlik: Değerlendirme Toplantısında, başarı belgesi dosyasının çeşitli akademik toplantılarda yüksek adette kullanıldığı, bundan dolayı mevcut ürüne yeni bir yaklaşım getirilebileceği konuşulmuştur. Yeni tasarımda, deri üzerine değerler logosu ve başlıklarını içeren görsel, Endüstriyel Tasarım Atölyesi’nde lazer kesimle uygulanmıştır (Görsel 11).
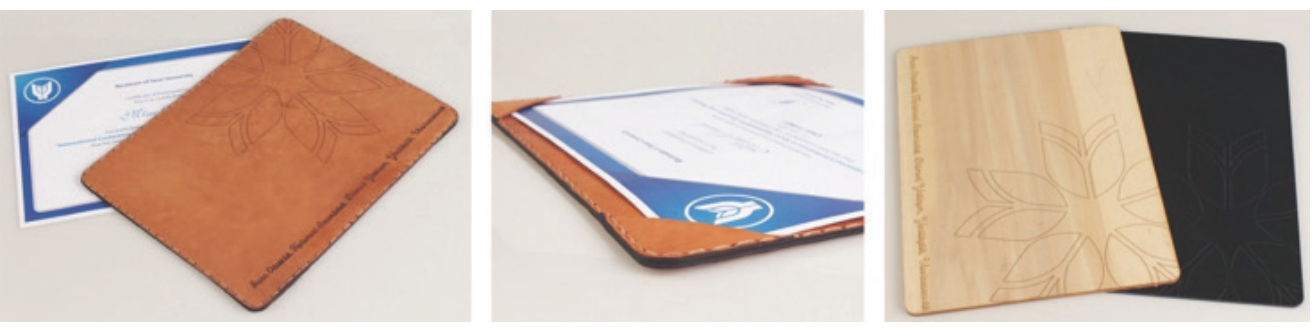

Görsel 11. Yeni tasarım-Başarı Belgesi Dosyası, M13 Sekreterlik.

4. Üst Düzey Kurumsal - Deri Ürünler: Üniversitede gün içerisinde çok kullanılan el çantası, kartlık ve taşıma aparatları prototipleri, kullanıma uygun olarak üretilmiştir. Değerlendirme Toplantısında, sapların bilekliğe benzetilmesi ve bilekliklerin de talep edilen ürünlerden olmasının belirtilmesi sonucunda, üzerinde değerlerin yer aldığg șerit deriler hazırlanmıştır (Görsel 12).
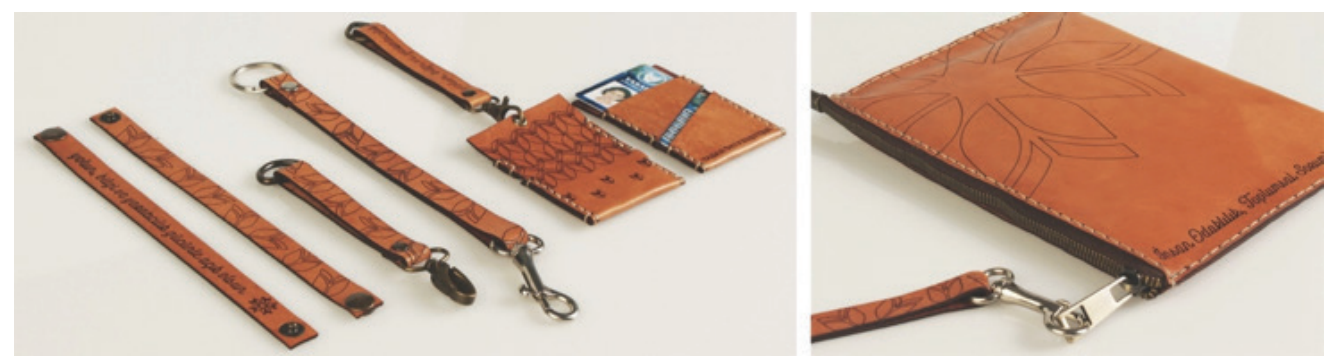

Görsel 12. M09 Anahtarlik 1, M11-M12 Kartlkk 1-2, M14 Deri Canta.

5. Üst Düzey Kişisel - Kahve Fincanı, Ahşap Altlık ve Ambalajı: Sanat ve Tasarım Yüksek Lisans Programı, Sağduyulu Tasarım adlı ders, “Tamir ve Tasarım” adlı proje kapsamında öğrenci İpek Atay’n ve daha sonra kendi atölyesinde geliştirerek ürettiği fincan tasarımı örnek bir uygulama olarak seçilmiştir. Bu proje için, gerekli tasarım iyileştirmeleriyle üniversite logosu uygulamasıyla üretilmesi öğrenciden talep edilmiştir. Seramik fincanın altında kullanılmak üzere masif ahşap bir altlık tasarımı yapılarak ürünün üniversite gündelik yaşamında hediye olarak yerini alabilmesi için ürün setlerinden "Her gün Herkes için” ve "Üst Düzey Kişisel Ürün” setine yerleştirilmiştir (Görsel 13). 

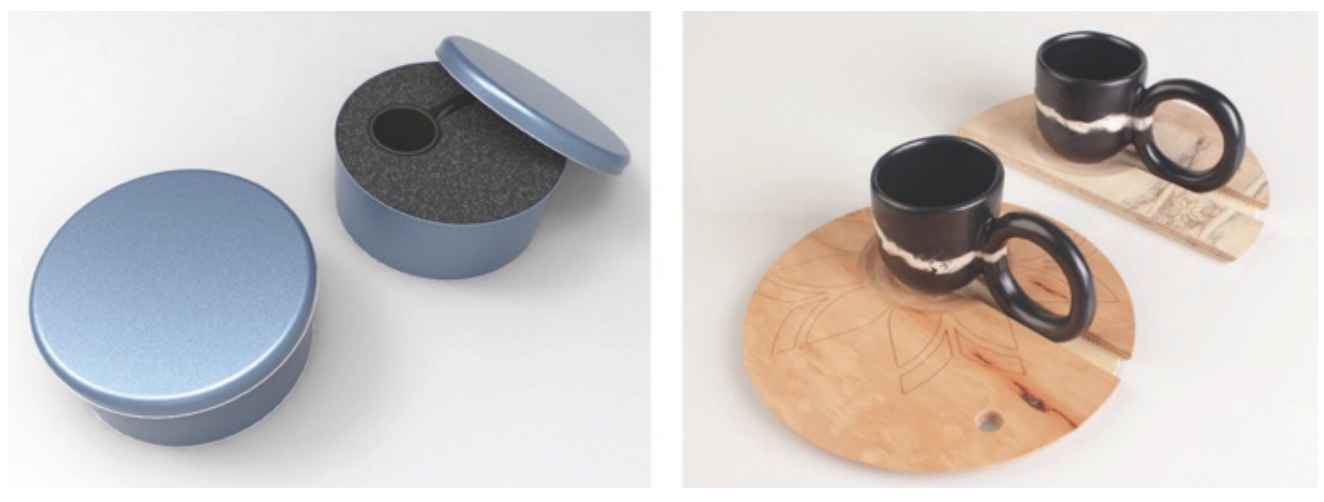

Görsel 13. M07 Kahve fincan seti ve ambalajı. Seramik kahve fincanı (tasarım: İpek Atay, YL öğrencisi)

6. Yerel Ürün - Zeytinyağı Sabunu, Sabunluk ve Ambalajı: Akdeniz kıyıları boyunca zeytin, zeytinyă̆ı, sabun üretimi yüzyıllardır süregelmektedir. Son on yılda, sıvı sabun tüketiminin artışı kalıp sabun kullanımını azaltımış olsa da tüketici doğal sabun arayışındadır. İzmir ve Ege Bölgesi’nde üretilen yerel ürün zeytinyağlı sabunun tasarımına ek olarak, ambalajda 4 adet sabun ile sunulabilecek mıknatıslı bir sabunluk tasarımı da eklenmiştir. Bu ürünlerin birer prototipi, Endüstriyel Tasarım Prototip Atölyesi’nde 3D yazıcıdan çıktı alınarak üretilmiştir. Bu şekilde geleneksel ve yerel bir ürün yeniden yorumlanarak özgün bir kent/kurum hediyelik nesnesi haline getirilmiştir (Görsel 14).

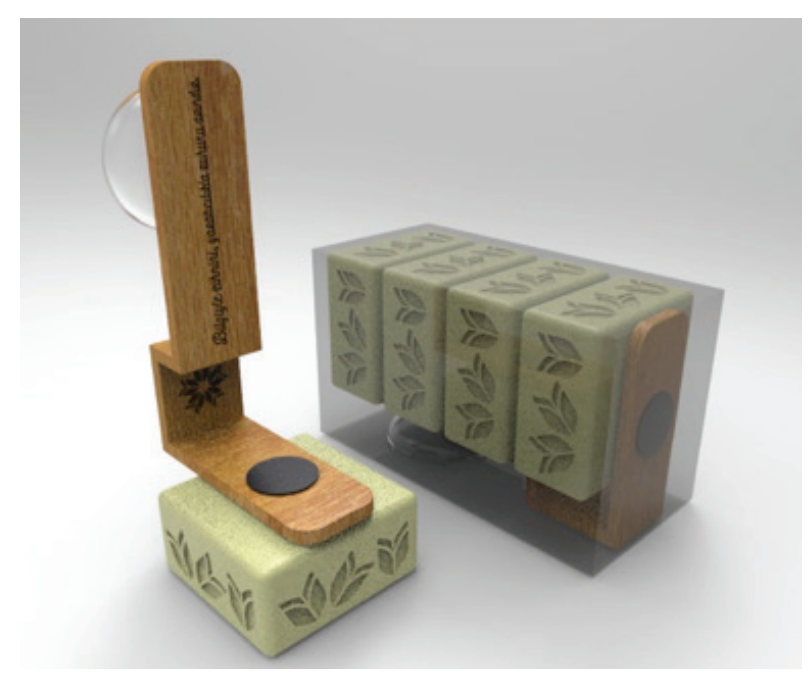

Görsel 14. M06 Zeytinyă̆ı Sabunu, Sabunluk ve Ambalajı.

7. Gıda - Çikolata ve Ambalajı: Kurumsal ziyaretlerde, olumsuz çağrışımı olmamasıyla tüm kültürlerde hediye için en "güvenli" ürünler arasında çikolata yer almaktadır. Çikolata tüketiminde ise dikkat çeken, "küçük bir parça" alma isteğidir. Bu sebeple, isteyenin daha küçük parçalarda tüketebileceği farkı boyutlara sahip çikolataları tek bir kalıpta toplayan bir ürün geliştirilmiştir. Ambalaj üst yüzeyinin, ürünü gösterecek şekilde transparan malzemeden ve alt kısmının gerekli bilgileri içerecek şekilde düz malzemeden üretilmesi düşünülmüştür. 

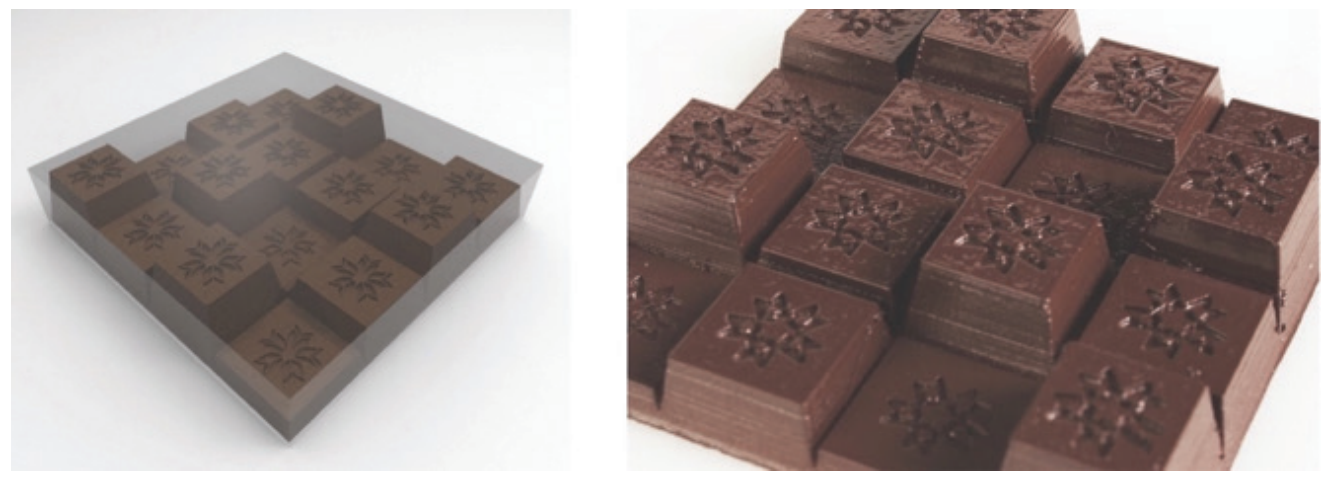

Görsel 15. M05 Çikolata.

8. Ambalaj ve Paketleme Malzemeleri: Bir ürünün hediye olarak tanımlanması, paketlenmiş olması ile mümkündür. Paketlemenin işlevi anlam katmanları yaratarak, nesnenin sadece kendisine değil, hediye vermenin önemi üzerine vurgu yapmaktır (Komter, 2007, 96). Bu sebeple, Hediye Yaşar logolu ana paket grubu dışında, üretilen diğer görsel serilerine de uygun ambalajlar tasarlanmıştır (Görsel 16).
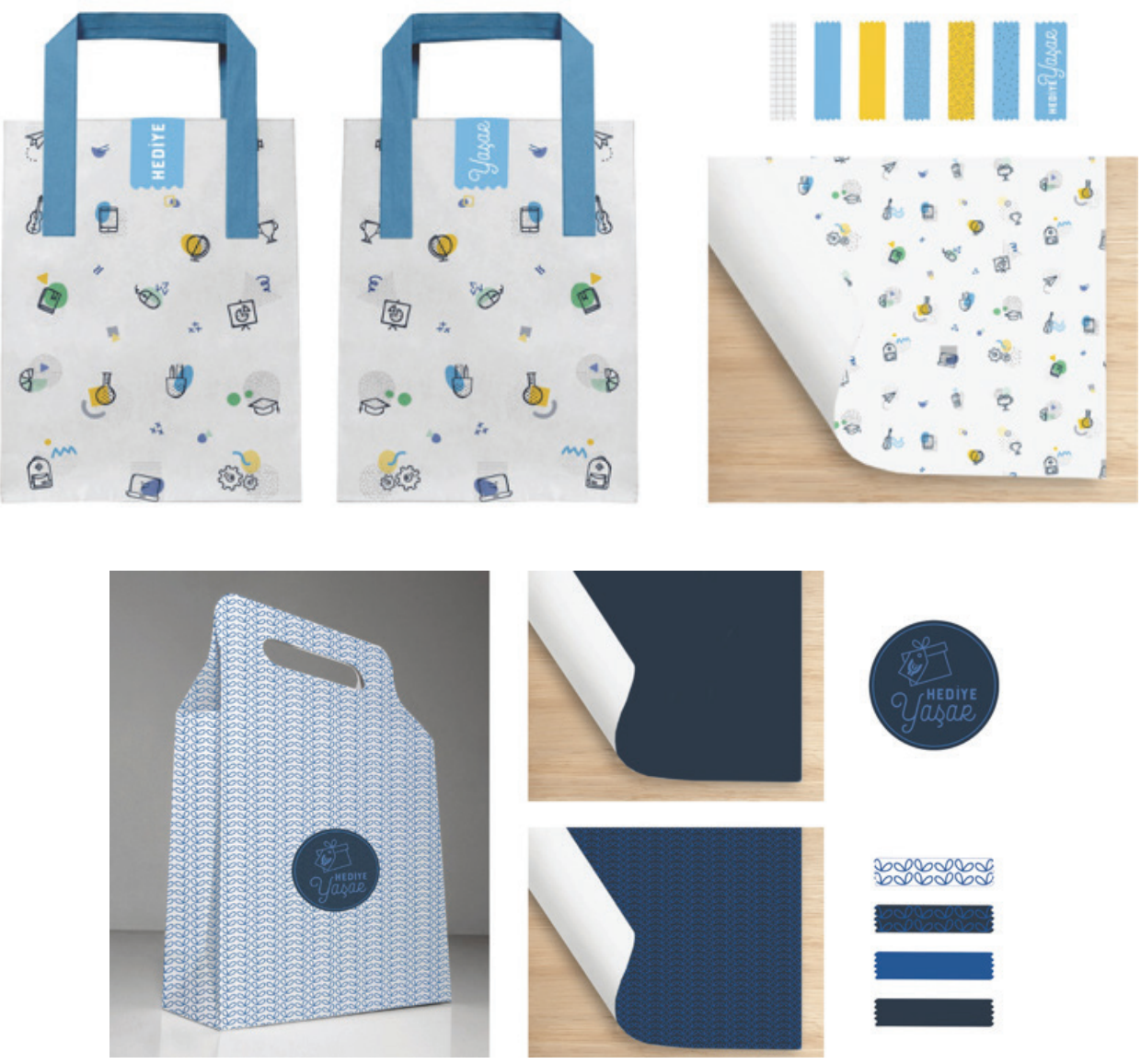

baboboc
baboboba

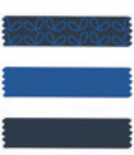

Görsel 16. Kağıt çanta, paket kă̆ıdı ve bant çeşitleri örnekleri. 


\section{SONUÇ}

Hediyelik eşyanın zihinlerde canlanan anlamı, kalitesiz seri üretim ya da kaliteli ama pahalı ürünler haline gelmiştir. Benzer algının tasarımcılarda da olması sebebiyle yakın zamana kadar tasarımcıların çalışma alanı olarak dikkatini çekmemiştir. Ancak, geleneksel / yerel üretim ve zanaatin çağdaş tasarım uygulamaları ile bir araya gelmesi yaklaşımı ile bu durum değişmektedir. Türkiye'de geleneksel ürün ve üretim yöntemlerinin barındırdığı potansiyel, tasarımcılar için dikkat çekici olmaktadır. Hediyelik eşyalar kentlere özgü gibi düşünülse de, üniversitelerde aidiyet duygusu oluşturma isteği ile gelişmeye yatkın bir konu olduğu görülmektedir.

Bu bağlamda, Bilimsel Araştırma Projesi olarak, araştırma odaklı tasarım yöntemi ile araştırma ve tasarım çalışmaları tamamlanmıştır. Sonrasında, üniversite paydaşlarına yönelik tasarlanan ürünlerin, üniversitede "hediye verme" ile ilgili birimleriyle yapılan değerlendirme toplantısında anket çalışması düzenlenmiştir (Ek.1). Katılımcıların, anketteki tablolarda belirtilen ürünleri üniversitenin beş değeri ile karşılaştırarak, çok-orta-az olarak sözel ve 5 ile 1 arası sayısal ölçütlerle değerlendirmeleri istenmiştir. Ayrıca, katılımcıların görevleri gereği hediye vereceği ve hediyelik eşya mağazası olması durumunda kişisel olarak hangi ürünleri satın alıp hediye vermek isteyecekleri bilgisi istenmiştir. Bu değerlendirme sonucunda; kişisel beğeni ve isteklerin her iki tercih açısından da önemli olduğu görülmüştür. Kişisel olarak kullanılmak istenilen ürünün aynı zamanda "gururla verilecek hediye" olduğu söylenebilmektedir.

Üniversite bünyesinde verilen hediye, özgünlügü, üretim yöntemi, işlevi ve estetiğiyle kurumun kültürünü ve değerlerini yansıttığı durumda, üniversite ile paydaşları arasında yeni etkileşimler yaratma potansiyeline sahip olmaktadır. Bu etkileşim, üniversitenin kültürünün ve değerlerinin korunması ve tanıtımına katkı sağlayacaktır. Tasarım değeri yüksek ürünlerin, kurumsal aidiyet duygusunu pekiştirdiği bilgisiyle yola çıkılan bu projede, kültür ürünleri üretiminde bir örnek model oluşturulmuştur. Öğrenci ve akademisyenin projelerde birlikte iş üretmesi, grafik tasarım ve endüstriyel tasarım atölyelerinin uygulamalarının bir amaç çevresinde toplanması, kurum içi üretim süreci ve yöntemlerini görünür kılmak, projenin öngörülen faydalaridir.

$\mathrm{Bu}$ çalışma kapsamında gelecekte, üniversite içinde bir kültür nesneleri tasarım ofisi kurulması, kampüs içinde hediyelik eşya mağazası kurularak üniversite bünyesinde tasarlanan ve üretilen ürünlerin bu mekanda ticarileştirilmesi, ürünlerin kent kültürü ölçeğinde geliştirilip yaygınlaştırılması önerilmektedir. Ürünlerin görünürlüğü, projeye dahil olan öğrencilere yeni kariyer fırsatları sağlayacaktır. Ayrıca, tasarımcı-katılımcı sayısı arttırılması için üniversitede öğrenci tasarım yarışmaları düzenlemek, üniversitede akademik kadronun tasarıma katkı sağlaması için projeler geliştirmek, üniversite-kent, üniversite-kurumlar arası iş birlikleri gibi genişletme projeleri hedeflenmelidir. 


\section{EK.1 Anket Çalışması}

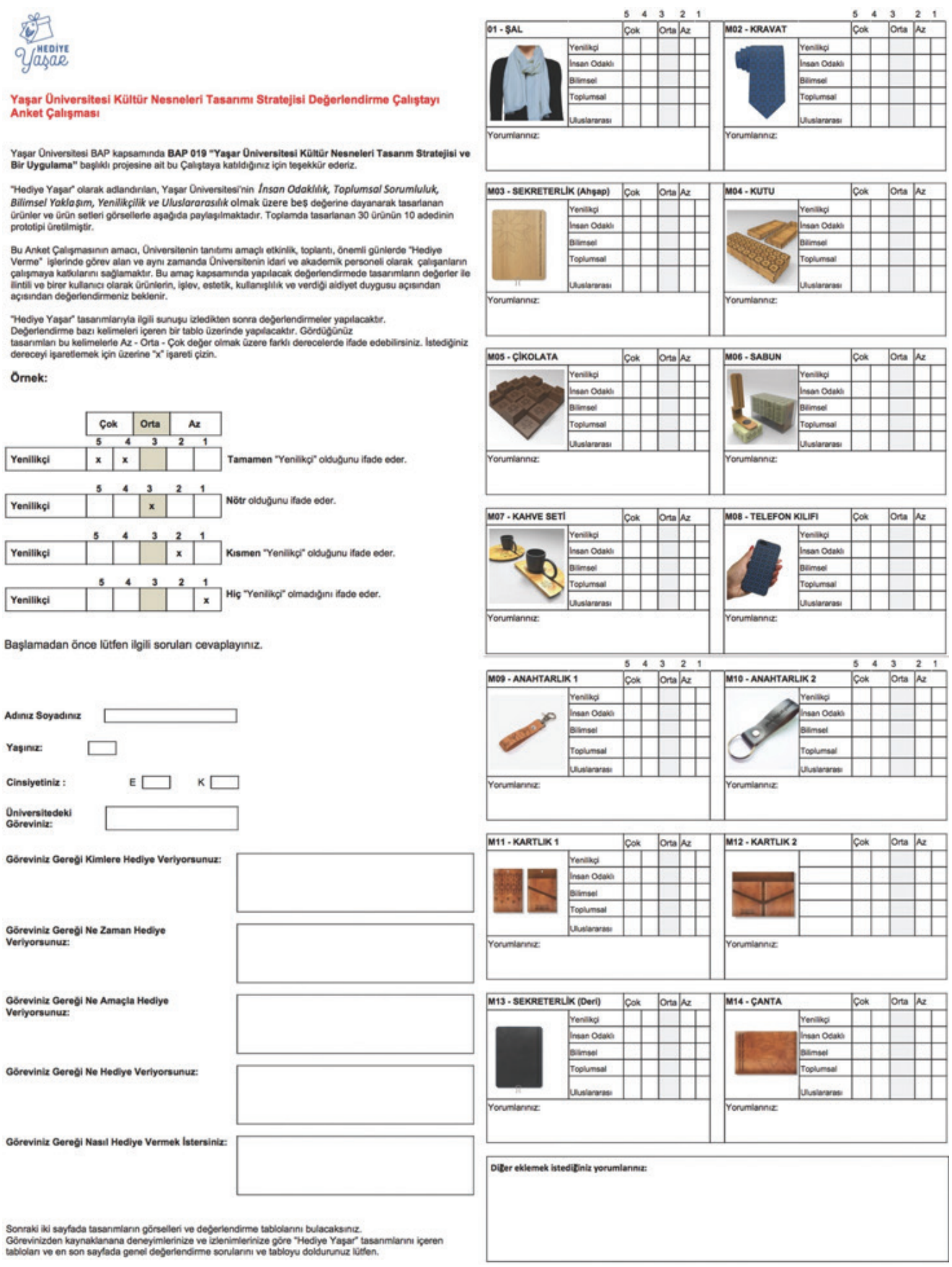




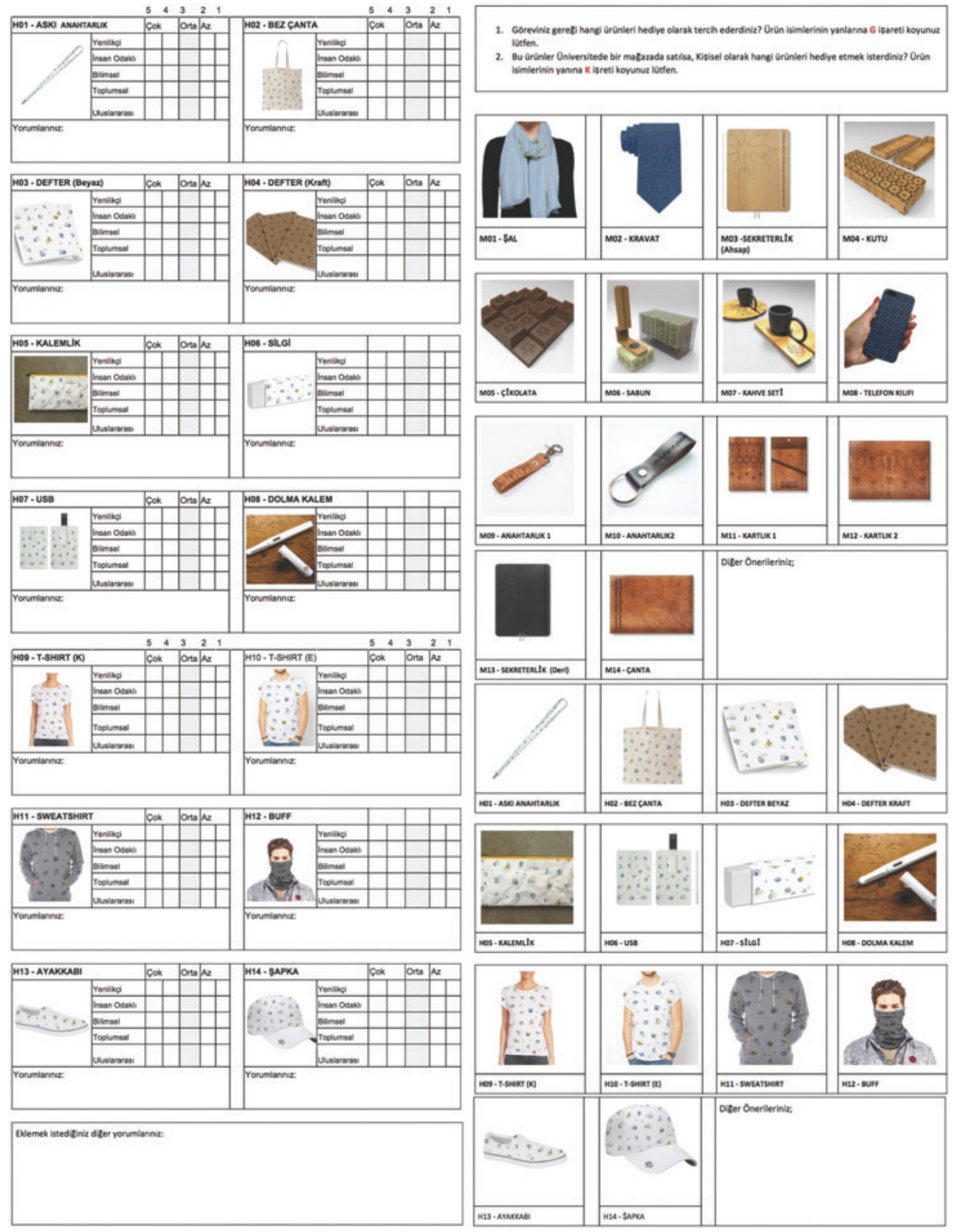




\section{KAYNAKÇA}

34-14 KHAS. (2013). (Kadir Has Üniversitesi) Ocak 7, 2017 tarihinde 34-14 KHAS: http://www.34-14khas.com.tr/aboutus adresinden alindi.

Alfody, S. (2007). NeoCraft: Modernity and The Crafts. Canada: The Press of The Nova Scotia College of Art and Design. Anderson, C. (2012). Makers: The New Industrial Revolution. New York: Crown Business.

Anderson, L. \& Littrell M. (1995). Souvenir-Purchase Behavior of Women Tourists. Annals of Tourism Research, 22, 328348 .

Asplet, M. \& Cooper, M. (2000). Cultural Designs in New Zealand Souvenir Clothing: The Question of Authenticity. Tourism Management, 21, 307-312.

Blundell, V. (1993). Aboriginal Empowerment and Souvenir Trade in Canada. Annals of Tourism Research, $20,64-87$.

Bolabola, C. A. (1980). The Impact of Tourism on Fijian Woodcarving. F. Rajotte içinde, Pacific Tourism: As Islanders See It. (93-97). Suva: Institute of Pacific Studies.

Chen Design Associates. (2011). Fingerprint: The Evolution of Handmade Elements in Graphic Design. Ohio: HOW Books. Coşar, M. (2008). Türk Kültüründe Hediyenin Algılanışı. İÜ Türk Dili ve Edebiyatı Dergisi, 38.

Cohen, J. H. (2001). Textile, Tourism and Community Development. Annals of Tourism Research, 28, 378-398.

Combrink, T. \& Swanson K. K. (2000). Souvenir Choice and Gender: An Evaluation of Domestic Souvenir Choice Attributes of Tourists in the Four Corners Region of the Southwest. Travel and Tourism Research Association Annual, (378-383).

de Kadt, E. (1981). Arts, Crafts and Cultural Manifestations. Ekistics, 48, 244-247.

Evans, G. (2000). Contemporary Crafts as Souvenirs, Artefacts and Functional Goods and their Role in Local Economic Diversification and Cultural Development. Hitchcock, $M$ \& Teague K. içinde, Souvenirs: The Material Culture of Tourism. (127-146). Aldershot: Ashgate.

Güvenç, B. (2007). Kültürün ABC’si. İstanbul: Yapı Kredi Yayınları.

Gordon, B. (1986). The Souvenir: Messenger of the Extraordinary. Journal of Popular Culture, 20(3), $135-146$.

Gormsen, E. (1981). Mexican Handicrafts Under the Influence of International Tourism: Development and Regional Employment. Ibero-Amerikanisches Archiv, 7, 77-110.

Graburn, N. H. (1976). Ethnic Tourist Arts: Cultural Expressions from the Fourth World. Berkeley: University of California Press.

İTÜ. (2017). İTÜ1173. https://www.1773itu.com adresinden alındt. Kim, S. \& Littrell, M. (1999). Predicting Souvenir Purchase Intentions. Journal of Travel Research, 38(2), 153-162.

Kim, S. \& Littrell, M. (2001). Souvenir Buying Intentions for Self versus Others. Annals of Tourism Research, 28(3), 638657.

Koepke, P. (2016). Patterns: Inside The Design Library. Phaidon Press.

Komter, A. (2007). Gift and Social Relations: The Mechanisms of Reciprocity. International Journal of Sociology, 22(1), 93-107.

Krippendorff, K. (2006). The Semantic Turn: A New Foundation for Design. Boca Raton: CRC/Taylor \& Francis.

Littrell, M., Anderson, L, Brown, P. (1993). What Makes a Craft Souvenir Authentic? Annals of Tourism Research, 20, 197-215.

Littrell, M., Baizerman S, Kean R., Gahring, S., Niemeyer, S., Reilly, R., \& Stout, J. (1994). Souvenirs and Tourism Styles. Journal of Travel Research, 33(1), 3-11.

Mauss, M. (1966). The Gift: Forms and Functions of Exchange in Archaic Societies. (I. Cunnison, Çev.) London: Cohen \& West.

Morbello, M. (1996). Zoo Veneers: Animals and Ethnic Crafts at the San Diego Zoo. Communication Review, 1(4), $521-543$.

Osgood, C., Suci, G., Tannnenbaum, P. (1957). The Measurement of Meaning. Chicago: University of Illinois Press. 
Schädler, K. F. (1979). African Arts and Crafts in a World of Changing Values. J. A. Kryden içinde, Tourism and Development (s. 146-156). Cambridge: Cambridge University Press.

Swanson, K. K., \& Horridge, P. (2002). Tourists' Souvenir Purchase Behavior and Retailers' Awareness of Tourists' Purchase Behavior in the Southwest. Clothing and Textiles Research Journal, 20(2), 62-76.

Swanson, K. K, Horridge, P. (2004). A Structural Model for Souvenir Consumption, Travel Activities and Tourist Demographics. Journal of Travel Research, 42(1), 372-380.

Swanson, K. K., \& Horridge, P (2006). Travel Motivations as Souvenir Purchase Indicators. Tourism Management, 27, 671-683.

Swanson, K. K. \& Timothy, D. J. (2012). Souvenirs: Icons of Meaning, Commercialization and Commoditization. Tourism Management, 33, 489-499.

The Harvard Shop. (2017). (Harvard University) Ocak 5, 2017 tarihinde The Harvard Shop: https://www.theharvardshop. com adresinden alindi.

Timothy, D. J. (2005). Shopping Tourism, Retailing and Leisure. Clevedon: Channel View.

University of Glasgow Shops. (2017). (U. o. Glasgow, Prodüktör) Ocak 6, 2017 tarihinde University of Glasgow Shops: https://www.universityofglasgowshops.com/pages/about-us adresinden alınd

Yu, H. \& Littrell, M. (2003). Product and Process Orientations to Tourism Shopping. Journal of Travel Research., 42, 140150. 
